\title{
Ultra-High Molecular Weight Polyethylene: Influence of the Chemical, Physical and Mechanical Properties on the Wear Behavior. A Review
}

\author{
Pierangiola Bracco ${ }^{1, *} \mathbb{D}$, Anuj Bellare ${ }^{2}$, Alessandro Bistolfi ${ }^{3}$ and Saverio Affatato ${ }^{4}$ \\ 1 Department of Chemistry and NIS (Nanostructured Interfaces and Surfaces) Center, University of Torino, \\ 10125 Torino, Italy \\ 2 Department of Orthopedic Surgery, Brigham and Women's Hospital, Harvard Medical School, Boston, \\ MA 02115, USA; anuj@alum.mit.edu \\ 3 CTO Hospital, Città della salute e della Scienza, 10126 Torino, Italy; abistolfi@cittadellasalute.to.it \\ 4 Medical Technology Laboratory, Rizzoli Orthopaedic Institute, 40136 Bologna, Italy; affatato@tecno.ior.it \\ * Correspondence: pierangiola.bracco@unito.it; Tel.: +39-011-670-7547
}

Received: 17 June 2017; Accepted: 8 July 2017; Published: 13 July 2017

\begin{abstract}
Ultra-high molecular weight polyethylene (UHMWPE) is the most common bearing material in total joint arthroplasty due to its unique combination of superior mechanical properties and wear resistance over other polymers. A great deal of research in recent decades has focused on further improving its performances, in order to provide durable implants in young and active patients. From "historical", gamma-air sterilized polyethylenes, to the so-called first and second generation of highly crosslinked materials, a variety of different formulations have progressively appeared in the market. This paper reviews the structure-properties relationship of these materials, with a particular emphasis on the in vitro and in vivo wear performances, through an analysis of the existing literature.
\end{abstract}

Keywords: UHMWPE; Ultra-high molecular weight polyethylene; oxidation; degradation; gamma radiation; crosslinking; Vitamin E; mechanical properties; wear

\section{Introduction}

Ultra-high molecular weight polyethylene (UHMWPE) has been used as a bearing material in total joint arthroplasty for more than 50 years now. The idea to replace degraded cartilage with a polymer liner dates back to the late 1950s. At that time, Sir John Charnley chose polytetrafluoroethylene (PTFE), a low friction polymer, as the bearing material to replace the natural acetabulum, articulating against a metallic femoral head, for hip replacement. Due to the unacceptably low wear resistance of PTFE though, the first "low friction arthroplasties" dramatically failed after few years of implantation. In 1962, UHMWPE, a similarly low-friction, but much more wear resistant polymer, replaced PTFE in Charnley's hip arthroplasty, with remarkably better performances. From then on, arthroplasty has known considerable evolution, but UHMWPE remains the gold standard for artificial hips and now other artificial joints, including the knee and shoulder [1].

Despite a relatively successful history, the steadily increasing number of yearly procedures [2,3] and, above all, the dramatic increase of demand in younger, more active patients [4] have stimulated a constant research for optimized material formulations and processing procedures, to ensure a high level of performance and durability.

Each potential innovation has been accompanied by a great deal of pre-clinical trials, performed by researchers all over the world, often with very different methods and sometimes with contradictory results. 
Only some of these studies were aimed at establishing a correlation between the chemical and morphological characteristics of the polymer and its mechanical properties and wear resistance. In some cases, retrieval studies have correlated the material properties to the clinical outcome of the implant.

The present work aims at exploring such a correlation through an analysis of the relevant literature that has appeared in the last decades.

\section{UHMWPE}

UHMWPE is a particular type of polyethylene (PE), with an exceptionally high molecular mass. The international Standards Organization (ISO 11542) (ISO, 2001) defines UHMWPE as having a molecular weight of at least 1 million $\mathrm{g} / \mathrm{mol}$, while the American Society for Testing and Materials (ASTM) specifies that UHMWPE has a molecular weight greater than 3.1 million $\mathrm{g} / \mathrm{mol}$ [5]. Besides the molecular mass, the microstructure of the polymer also plays an important role in determining its physical, chemical and mechanical properties. UHMWPE, as most polyethylenes, is a semi-crystalline polymer composed of at least two interpenetrating phases: a crystalline phase, in which the macromolecules fold into ordered, crystalline lamellae and an amorphous, disordered phase, possibly intercalated by a partially ordered, so called all-trans, interphase [6,7].

The UHMWPE used in orthopaedic applications typically has a molecular weight between 3.5-6 million [8] and semi-finished bars and rods have a degree of crystallinity ranging around $50-55 \%$. Such a precise combination of chemical structure, molecular mass and microstructure is at the basis of the peculiar balance of high mechanical properties and wear resistance that has made UHMWPE the material of choice in arthroplasty. A high entanglement density is associated with the ultra-high molecular weight; entanglements behave like physical crosslinks, which affect its crystalline morphology when the polymer is melt-crystallized. Unlike its lower molecular weight counterparts, UHMWPE crystallizes into a non-spherulitic structure comprising tortuous, defective lamellae. The high entanglement density is responsible for the relatively low crystallinity, compared to medium and low molecular weight, linear, high density polyethylene (HDPE) which can be melt crystallized to a degree of crystallinity of $70-80 \%$. It is generally believed that the higher toughness and wear resistance of UHMWPE is associated with a large number of inter-lamellar tie molecules connecting adjacent lamellae, compared to HDPE. Furthermore, inter-spherulitic boundaries of HDPE are known to be weak since melt crystallization "sweeps" any impurities present in the melt to spherulitic boundaries which are also thought to contain a larger concentration of chain ends than the amorphous layers between lamellae. The suppression of spherulite formation in UHMWPE then must also contribute to the overall toughness and high wear resistance of UHMWPE. UHMWPE resin has an essentially zero melt flow index. As a result, upon melting of UHMWPE resin particles, that are usually approximately $50-150 \mu \mathrm{m}$ in diameter, do not flow and instead retain their shape. This makes it extremely difficult to injection mold the powder to directly constitute implants and instead, the resin is compression molded or ram extruded into bars at elevated pressure and temperature, and then annealed to remove residual stresses. It is then machined into implants, packaged and sterilized prior to implantation.

It is quite clear that any processing step must be carefully controlled, from consolidation of the powder at elevated temperatures and pressures, to radiation sterilization, to addition of antioxidants or anti-slip agents or to any other specific treatment that can potentially influence such a balance and thus lead to changes in macroscopic mechanical and tribological properties As with any semicrystalline polymer, the microstructure and nanoscale lamellar morphology of UHMWPE depends on its thermal history during molding or ram extrusion. Unlike PEs with lower molecular weight, the consolidation of UHMWPE resin particles is a slow process due to the large time scales associated with reptation of chains of high molecular weight across resin boundaries to entangle with chains in adjacent resin particles and co-crystallize to form a fused article, assisted by pressure and temperature. Chain reptation, derived from the word "reptile", is the thermal motion of entangled macromolecules 
in a tube, much like the slithering of snakes. In fact, it has been demonstrated that the extended-chain morphology of the UHMWPE resin upon melting leads to "chain-explosion" which is the dominant transport mechanism that leads to cocrystallization of chains across resin boundaries to fuse the resin, compared to the much slower chain reptation process [9]. The difficulty in fusion of resin particles makes the inter-powder boundaries weaker than the interior of resin particles, but overall provides a tough, highly wear resistant material with a relatively successful history of implantation as joint replacement devices.

\section{3. "Historical" and Conventional Radiation Sterilized Polyethylenes}

The term "historical" often identified polyethylenes that were sterilized by 25-40 kGy of gamma radiation in air [10]. These types of polyethylene have a long clinical history, starting from the first pioneering implants in the 1960s, up to the end of the 1990s, by which time most manufacturers had switched to inert-sterilized, barrier packaging PE and/or to crossliked PE. However, examples of gamma air sterilized polyethylenes can also sporadically be found in contemporary clinical applications [10,11].

A body of literature, in particular across the late 1980s to the early 2000s, investigated the effects of radiation sterilization in air on the chemical, physical, mechanical and tribological properties of polyethylene [12-18]. Basically, high energy irradiation leads to the cleavage of chemical bonds of the PE chains, creating free radicals. The free radicals are highly reactive species that tend to produce a complex series of reactions, the extent of which is strongly dependent on the surrounding species available for reaction [19]. In inert atmosphere, the predominating effect of irradiation is the formation of crosslinks among the polymer chains. Conversely, in an air environment, the radicals can easily react with oxygen, triggering a cyclic, auto-sustained process that results in the formation of oxidation products on the backbone of the polymer and, more importantly, in predominating chain scissions, with a consequent overall decrease in its molecular mass, and significant changes to its morphology (Figure 1). In particular, it has been demonstrated that, immediately after irradiation in air, crosslinking and an increase in crystallinity are the dominant processes. With time, chain scission induced by oxidation prevails, resulting in a further increase in crystallinity [20-22], likely through the formation of a new phase of thinner crystallites in the amorphous region [13].

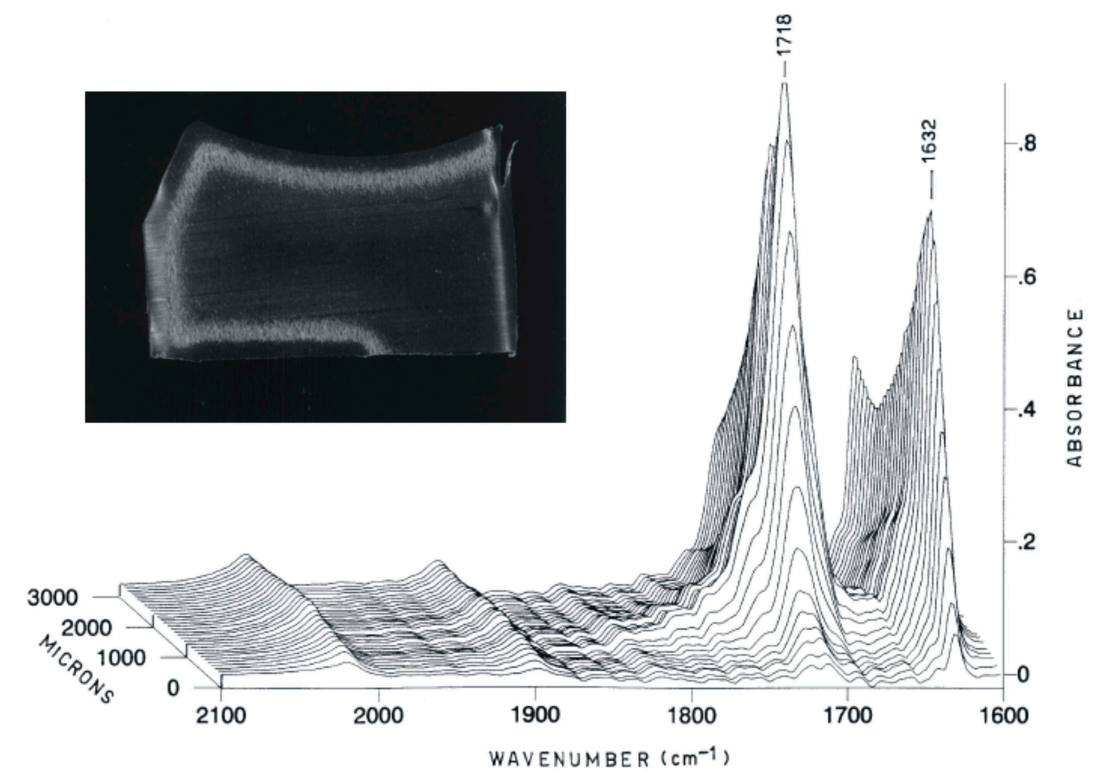

Figure 1. Cross-section of a gamma-air sterilized tibial insert, exhibiting a characteristic "crown-effect" (subsurface white band), along with its Fourier Transform InfraRed (FTIR) spectra, showing the presence of abundant oxidation products. Adapted from [17], with permission. 
The extent and rate of radiation-induced oxidation depends on several factors, including the total absorbed dose and dose rate, the temperature of the sterilization facility, the oxygen availability and the sample thickness, which in turn governs the oxygen concentration distribution through the thickness of the implant. In addition, the oxidative process initiated during sterilization can continue, with variable yet low rates, during shelf storage and implantation (post-irradiation aging). Again, the rate and extent of oxidative degradation depend on the shelf-aging time and temperature and on the amount of available oxygen in the shelf and in vivo [19]. Further, it appears that mechanical stresses developed during in vivo use can also facilitate the oxidative process [23,24]. In summary, it follows that sterilization by high energy radiation in the presence of air can result in highly variable oxidation levels in polyethylenes, influenced by multiple factors.

Overall, oxidative degradation has been demonstrated to lead to significant changes in the mechanical properties of UHMWPE and, in particular, to embrittlement. Brittleness of polymers is well known to be correlated to the tensile properties $[25,26]$. Accordingly, an increase in elastic modulus and a decrease in the elongation to failure, ultimate stress and toughness has been demonstrated by a number of studies [27-29] (Figure 2); moreover, a decrease in fatigue crack propagation resistance has also been observed [20,30], while an often dramatic decrease in wear resistance (Figure 3 ) has been demonstrated by multiple in vitro and retrieval studies [22,29,31-34].
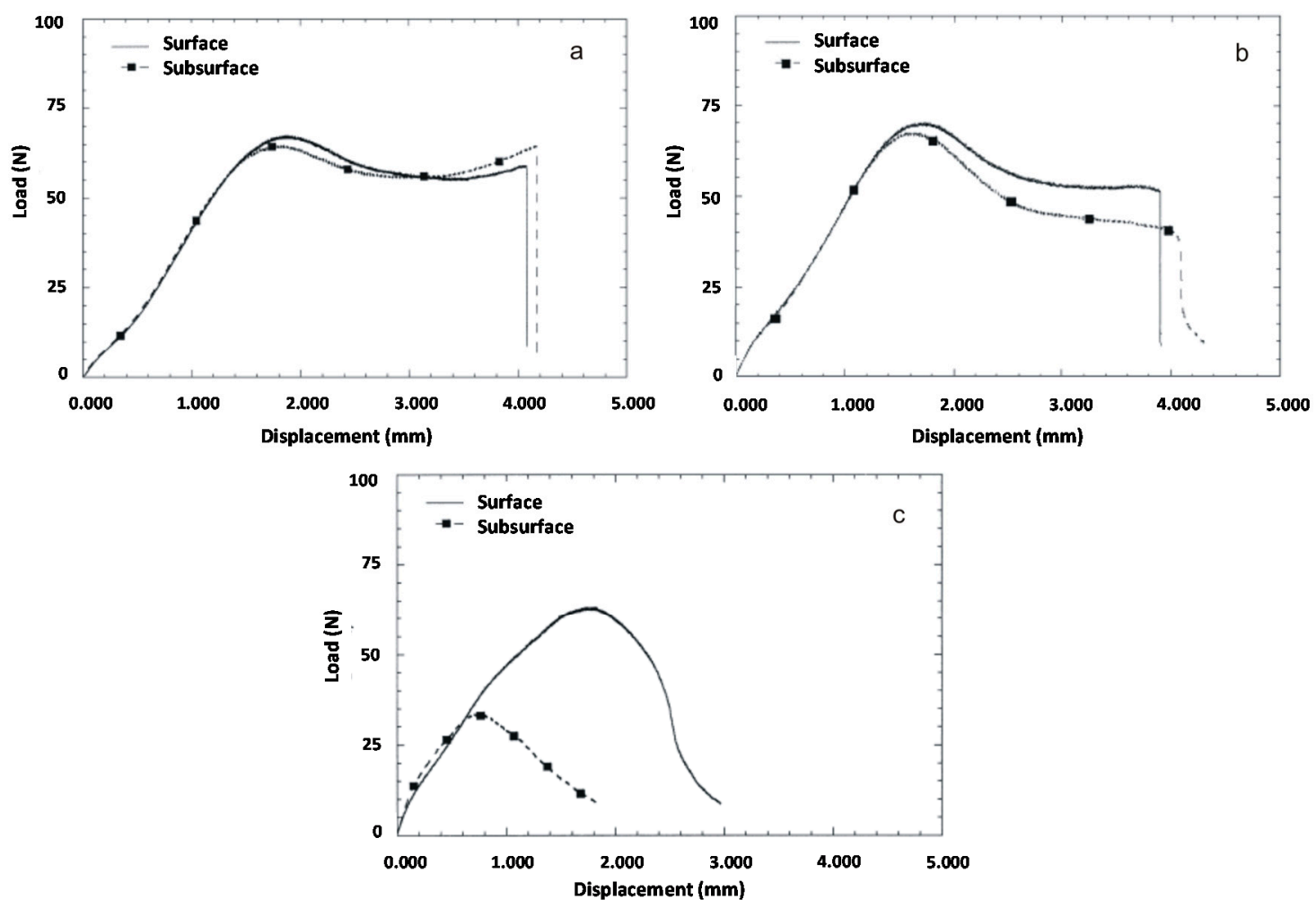

Figure 2. Small punch load displacement curves for gamma-air sterilized ultra-high molecular weight polyethylene (UHMWPE) tibial inserts at surface and subsurface locations: (a) control, unaged; (b) shelf-aged for 5 years; (c) shelf aged for 10 years. Adapted from [27], with permission.

Wear in this material has typically been measured as weight loss per million cycles after accounting for absorption of bovine serum during articulation against a metal or ceramic counterface. A control specimen is typically loaded and soaked in bovine serum but not articulated and fluid absorption is measured periodically along with worn specimens. Wear rate has also been reported as wear factor, which is the weight loss normalized by load and the total wear path traveled $[35,36]$. 
It is worth mentioning though, that several in vitro studies reported markedly better wear performances of gamma-air irradiated polyethylenes vs. unirradiated ones. For example, Essner and coworkers [37], in a comprehensive study investigating the clinical relevance of hip simulator experiments, demonstrated that the wear volume of non-sterilized and EtO sterilized cups was twice that of gamma-irradiated in air cups. Similarly, Affatato et al. [38] showed that after 5M cycles in a hip simulator, EtO-sterilized specimens wore 1.2 times faster than those gamma-irradiated and the same result was confirmed even in a subsequent test in a regime of third-body wear [39]. McKellop et al. [40], in another hip simulator experiment, also found indistinguishable wear rates for two cups, both gamma-irradiated in air, made of different resins (GUR 4150 and 1020, with and without calcium stearate), and a 54\% higher wear rate for a cup made with the same GUR 4150 resin, sterilized with ethylene oxide.

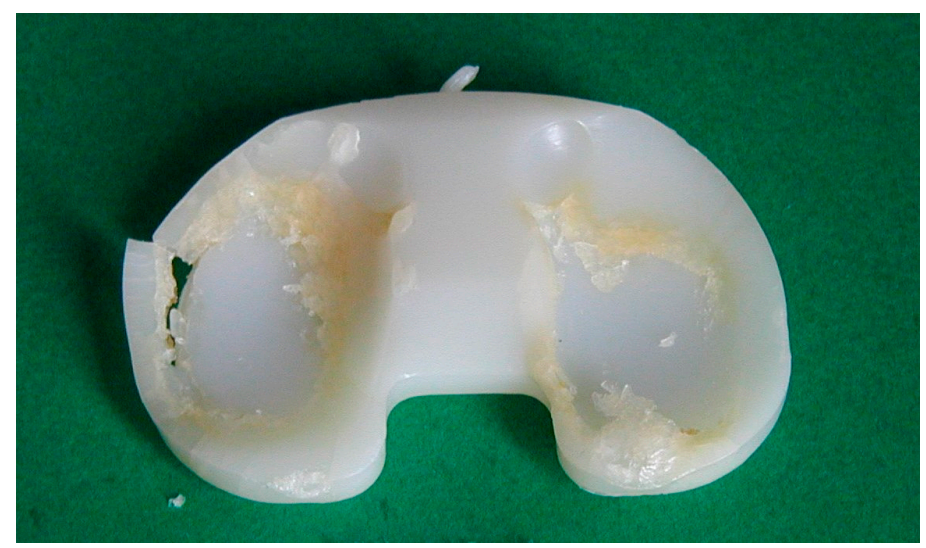

Figure 3. Retrieved polyethylene tibial insert showing severe wear damage, including severe delamination and wear (10 years in vivo).

This likely occurs because, as highlighted above, gamma irradiation results in a combination of crosslinking and chain scission, the latter prevailing only after an extended time of post irradiation aging. Given the opposite effect of these two phenomena on the wear resistance of UHMWPE $[17,33,41,42]$, it becomes apparent that radiation sterilized samples will exhibit less wear of unirradiated or EtO/gas plasma sterilized ones, at a short post irradiation time scale and storage conditions that allow crosslinking to prevail to a larger extent than chain scission. On the contrary, after suitable accelerated ageing or longer real time aging, in the shelf or in vivo, the wear and fatigue performances of gamma irradiated samples deteriorate considerably as a consequence of oxidative degradation and negate any short term benefits of crosslinking associated with sterilization methods that use ionizing radiation $[21,29,32,33,43]$.

This observation prompted researchers in the field to implement strategies to take advantage of the benefit of the crosslinking induced by radiation treatments, yet minimizing the drawback of long-term oxidation.

The first adopted measure was to sterilize UHMWPE with high energy radiation in a low-oxygen environment (vacuum or inert gas, i.e., argon or nitrogen) [10,44-46]. This practice avoids contact with oxygen during sterilization and, if the liner is wrapped in a suitable barrier packaging, during the following shelf life as well [11,47]. Unfortunately, it does not prevent contact with the oxygen solubilized into polyethylene before packaging in the low-oxygen environment, nor with that available in vivo [43], so that some oxidation has also been observed in these polyethylenes, even if to much lower levels than for those radiation sterilized in air [11,48,49]. 


\section{1st Generation Highly Crosslinked Polyethylene}

\subsection{Improving the Wear Resistance}

By the late 1990s, a large number of laboratory and clinical studies indicated that crosslinking provides substantial improvement in the wear resistance of UHMWPE. The mechanisms by which this improvement occurs were elucidated by various researchers [41,42,50-52]. Basically, wear of UHMWPE is believed to take place via plastic deformation of the polymer, with molecular alignment in the direction of motion that results in the formation of fine, drawn-out fibrils oriented parallel to each other. As a result of this arrangement, the UHMWPE wear surface may strengthen along the direction of sliding, while it weakens in the transverse direction. Wang et al. [50] concluded that, under the conditions of multi-directional motion, which may apply to both the hip and the knee joint, this orientation-softening phenomenon is predominantly responsible for the detachment of fibrous wear debris from the worn surfaces that have been observed in many reports [53-55]. Therefore, it has been postulated that, since crosslinking induces carbon-carbon bonds between adjacent chains, hereby reducing the chain mobility and inhibiting such molecular orientation, it would have been efficient in slowing down the formation of surface fibrils and rendering the polyethylene more resistant to wear $[41,51,56]$.

Although some controversies do exist in the literature, regarding the chemical mechanisms of radiation crosslinking of UHMWPE [19,56-58], most authors agree that the crosslinking density increases linearly up to radiation doses in the order of $100 \mathrm{kGy}$, above which it tends to a plateau (Figure 4a) [42]. However, the decrease in the tensile and fracture toughness continues at a radiation dose higher than $100 \mathrm{kGy}[59,60]$. Therefore, most of the "1st generation" highly crosslinked polyethylenes appeared in experimental in vitro and clinical studies at the end of the 1990s and in the early 2000s were irradiated to doses between 50 and $105 \mathrm{kGy}$ [5].
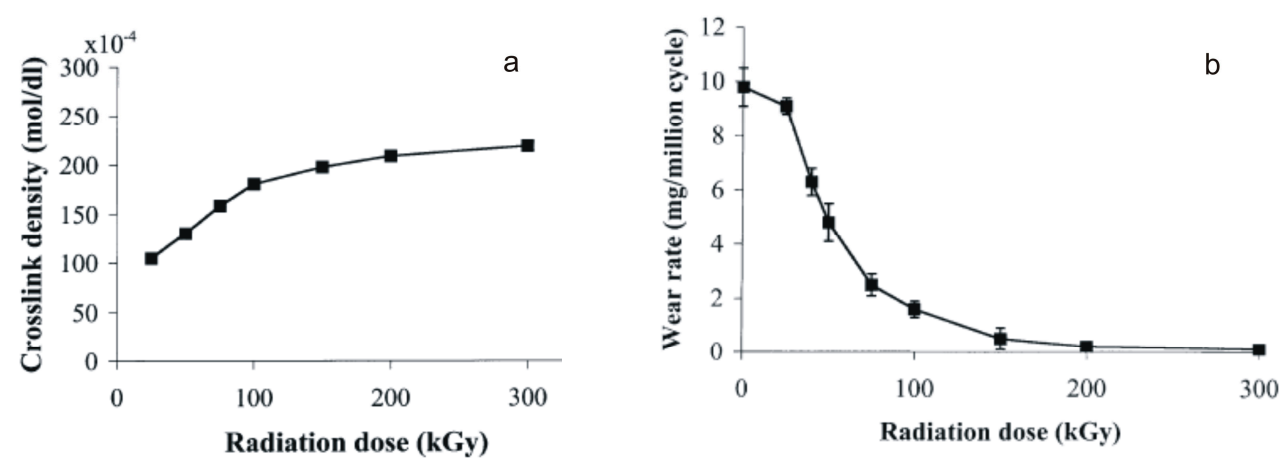

Figure 4. (a) Crosslink density and (b) pin-on-disk (POD) wear rate of irradiated UHMWPE as a function of increasing dose. Adapted from [42] with permission.

\subsection{How to Prevent Oxidation}

However, as mentioned in the previous paragraph, numerous studies had already demonstrated an unacceptably low stability to oxidation of irradiated polyethylene. As a consequence, stabilization strategies were developed in order to minimize post-irradiation oxidative ageing. Basically, two different strategies were adopted: one involved post-irradiation melting of the polyethylene (remelting) [41,56], while the other included a thermal treatment, as well, but at a temperature below complete melting of the crystallites (annealing) [61,62]. In both cases, the rationale for the protocol was to eliminate or reduce the residual radicals, trapped in the crystalline phase of the polymer, as to avoid the oxidation cascade. 


\subsection{Microstructure, Mechanical Properties and Wear}

Irradiation of polyethylene results in a slight increase in crystallinity with increases in the radiation dose, along with a marked decrease in elongation to failure and impact strength, a moderate decrease in ultimate strength and a slight increase in yield strength [41,63]. Post-irradiation remelting causes a significant decrease in crystallinity, accompanied by a reduction in yield and ultimate strengths $[61,63]$ This likely occurs because the kinetics of crystallization is affected by the formation of a network structure due to the presence of crosslinks, which reduce the chain mobility and makes it more difficult for PE macromolecules to reptate and enter into growing lamellae. As a consequence, recrystallization of a radiation crosslinked UHMWPE always results in decreases in crystallinity [56,64]. Such a decrease in crystallinity is also associated to a decrease in fatigue resistance (Table 1$)[30,60,63,65-67]$. On the contrary, post-irradiation annealing does not cause a reduction in crystallinity, thus preserving superior yield, ultimate and fatigue properties, with respect to remelting [61,65-67], at least in the short term.

Table 1. Physical properties and fatigue crack propagation data for a set of standard and crosslinked/remelted UHMWPE (GUR 1050), at increasing gamma radiation doses. All crosslinked samples were remelted at $170{ }^{\circ} \mathrm{C}$ for $4 \mathrm{~h}$ and subsequently annealed at $125^{\circ} \mathrm{C}$ for 2 days. Adapted from [60] with permission.

\begin{tabular}{ccccc}
\hline & Control & $\mathbf{5 0 ~ k G y}$ & $\mathbf{1 0 0 ~ k G y}$ & $\mathbf{2 0 0} \mathbf{~ k G y}$ \\
\hline Crystallinity (\%) & $50.1 \pm 0.5$ & $45.6 \pm 0.7$ & $46.3 \pm 0.8$ & $47.1 \pm 0.4$ \\
Lamellar thickness (nm) & 20.0 & 18.1 & 18.7 & 19.1 \\
Elastic modulus (MPa) & $495 \pm 56$ & $412 \pm 50$ & $386 \pm 23$ & $266 \pm 30$ \\
Yield stress (MPa) & $20.2 \pm 1.0$ & $19.9 \pm 0.8$ & $18.9 \pm 0.7$ & $20.2 \pm 1.0$ \\
True stress at break (MPa) & $315.5 \pm 31.6$ & $237.6 \pm 12.3$ & $185.7 \pm 7.5$ & $126.0 \pm 14.0$ \\
Decrease in true stress at break (\%) & - & 24 & 41 & 60 \\
$\left.\mathbf{\Delta} \mathbf{K}_{\text {incep }} \mathbf{( M P a} \sqrt{ } \mathbf{m}\right)$ & 1.41 & 0.91 & 0.69 & 0.55 \\
Decrease in $\mathbf{\Delta} \mathbf{K}_{\text {incep }} \mathbf{( \% )}$ & - & 35 & 51 & 61 \\
\hline
\end{tabular}

Both highly crosslinked formulations demonstrated superior wear resistance during in vitro tests, when compared to unirradiated or conventional gamma air/gamma inert sterilized polyethylenes.

For example, the wear rates measured using a bi-directional pin-on-disk (POD) on a set of polyethylenes, e-beam irradiated at room temperature in air to doses ranging from 25 to $300 \mathrm{kGy}$ and subsequently melted $\left(150^{\circ} \mathrm{C}\right.$ for $2 \mathrm{~h}$ under vacuum), were found to decrease sharply with increasing the radiation dose: from $9.6 \pm 0.7 \mathrm{~g} /$ million cycles for the control, unirradiated sample, to $1.6 \pm 0.3 \mathrm{~g} /$ million cycles for the $100 \mathrm{kGy}$ irradiated and remelted sample, approaching an undetectable wear rate for radiation doses of the order of $300 \mathrm{kGy}$ (Figure 4b) [42].

Similarly, acetabular cups machined from a polyethylene gamma-irradiated in air at doses ranging from 33 to $1000 \mathrm{kGy}$, remelted and EtO sterilized, demonstrated an $87 \%$ wear reduction with increase in the radiation dose from 33 to $95 \mathrm{kGy}$, when tested for 5 million cycles in a hip simulator; again, the wear decreased to undetectable levels at a radiation dose higher than $200 \mathrm{kGy}$ [41]. In the same work, by observing the trade-off between the reduction in tensile properties and the increase in wear resistance with increasing the radiation dose, the authors concluded that approximately $100 \mathrm{kGy}$ represents the most appropriate dose to reduce the wear below the threshold for clinically significant effects, simultaneously preserving sufficient tensile properties.

Kurtz et al. [61] summarized the wear test results of seven independent hip simulator studies, all using the same hip simulator design and comparable conditions, of a conventional, gamma inert sterilized polyethylene (30 kGy gamma radiation, in nitrogen: N2-Vac ${ }^{\mathrm{TM}}$ Stryker Howmedica Osteonics, Mahwah, NJ, USA) vs. a highly crosslinked and annealed UHMWPE (75 kGy gamma radiation, annealing at $130^{\circ} \mathrm{C}, 30 \mathrm{kGy}$ gamma radiation in nitrogen for sterilization purpose, Crossfire ${ }^{\mathrm{TM}}$, Stryker Howmedica Osteonics, Mahwah, NJ, USA). Counterfaces included CoCr, alumina, and Zirconia ceramic femoral heads with sizes ranging between 28 and $36 \mathrm{~mm}$. The linear wear rate was calculated in the first 2 to 3 million cycles of the test to facilitate comparison between studies. Despite a relatively 
broad distribution in wear rates, which may be partly explained by variations in liner design, femoral head material, and femoral head size, the survey demonstrated a $92 \%$ reduction in median wear rate for the highly crosslinked and annealed UHMWPE, relative to the conventional, gamma inert sterilized polyethylene.

\subsection{Does the Counterface Matter with Crosslinked Polyethylene?}

The influence of the type of counterface on the wear behavior of crosslinked polyethylene was also investigated. Bistolfi and coworkers [64] showed that a moderate dose (50 kGy) of radiation crosslinking increased the wear resistance of UHMWPE against a CoCr counterface in a POD apparatus 7-fold, but the coupling of remelted, crosslinked UHMWPE against a smoother alumina counterface led to a 20-fold increase in wear resistance. Affatato et al. [68] tested e-beam highly crosslinked and remelted hip liners $\left(95 \mathrm{kGy}\right.$ at $40{ }^{\circ} \mathrm{C}$, thermally treated at $150{ }^{\circ} \mathrm{C}$ for $6 \mathrm{~h}$, Gas Plasma sterilized. Longevity $^{\mathrm{TM}}$, Zimmer Inc., Warsaw, IN, USA) in a hip simulator for $3 \mathrm{M}$ cycles, against deliberately scratched femoral heads (mean surface roughness, Ra: 0.12-0.14 $\mu \mathrm{m}$ ). Even in such demanding conditions, they reported a 40 times lower wear rate for the crosslinked material than for conventional, gamma-nitrogen sterilized UHMWPE.

A previous study [36] also demonstrated that moderately crosslinked UHMWPE (40 kGy in vacuum, no thermal treatment) exhibited a 30\% reduction in wear rate compared to unirradiated polyethylene, when articulating on smooth $\mathrm{CoCr}$ femoral heads. However, upon intentionally scratched $\mathrm{CoCr}$ femoral heads the wear rate was found to be higher for the moderately crosslinked polyethylene than for the non-crosslinked materials. Most importantly, the moderately crosslinked polyethylene generated a higher percentage volume of smaller, more biologically active particles, thus resulting in a similar index of functional biological activity. The authors concluded that this evidence provides a clear message that is preferable to use crosslinked materials against damage-resistant ceramic heads, to prevent the possibility of wear acceleration owing to third body damage to metallic femoral heads. Another study by the same group [69] demonstrated a fivefold lower wear for 75 and $100 \mathrm{kGy}$ gamma irradiated and remelted polyethylenes, compared to control unirradiated or $25 \mathrm{kGy}$ irradiated in air, when tested for $5 \mathrm{M}$ cycles in a hip simulator, against CoCr femoral heads. The wear reduction was found to be significantly higher for the material irradiated to $100 \mathrm{kGy}$. In this experiment, a large reduction in the functional biological activity of the wear particles generated by the highly crosslinked material was also observed and it was attributed to the overall lower wear volume found with this material. The same study also highlighted the influence of "bedding-in", due to creep deformation, on the greater wear volume observed in the first million cycles for all polyethylene configurations.

\subsection{Thermal Treatments and Oxidation Stability}

Regarding the oxidation stability of the two formulations of 1st generation highly crosslinked polyethylenes, McKellop and coworkers compared the oxidation stability and wear resistance of the same set of samples mentioned above [41], with or without remelting, following accelerated ageing at $80{ }^{\circ} \mathrm{C}$ in air for 20 to 30 days. The remelted cups exhibited little or no oxidation after artificial aging and no white bands, that are generally interpreted as a visual indication of oxidation [17], were present on the cross sections of the remelted cups. In contrast, without remelting, there was considerable oxidation of the crosslinked cups, with subsurface oxidation peaks. White bands were present on the cross sections at the levels corresponding to maximum oxidation. Despite this oxidation, the wear rates of the cups, with or without remelting, were comparable before and after aging. However, it was observed that, being that the oxidized zones were located about $0.5 \mathrm{~mm}$ below the surface and given the low wear rates of the crosslinked cups, the wear did not penetrate into the oxidized layers of the not remelted cups, under the conditions of the experiment, but that, likely, this subsurface oxidation could cause an increase in the wear rate after extended clinical use. This observation prompted the authors to postulate that remelting is an essential step to optimize the long-term performance of crosslinked cups. 
Muratoglu and coworkers [70] tested the oxidative stability of two highly crosslinked polyethylenes, one of which had been ebeam irradiated to $100 \mathrm{kGy}$, remelted $\left(150{ }^{\circ} \mathrm{C}, 2 \mathrm{~h}\right)$ and terminally gas plasma sterilized, while the other had been gamma irradiated to $75 \mathrm{kGy}$, annealed below the melting temperature $\left(120^{\circ} \mathrm{C}\right)$ and gamma sterilized $(25-35 \mathrm{kGy})$ in nitrogen. The POD wear rates of the two unaged samples were comparable and much lower than those of conventional, uncrosslinked samples. Residual free radicals were detected in the annealed samples by Electron Spin Resonance (ESR), while they were not found in the remelted samples. Following accelerated ageing in air at $80^{\circ} \mathrm{C}$ for 3 weeks, the annealed samples developed significant oxidation and their wear rate was found to increase by over an order of magnitude, while no oxidation or significant changes in the wear rate were observed for the remelted formulation.

In another study [71], the same annealed formulation was compared to a warm irradiated (95 kGy at $120^{\circ} \mathrm{C}$ ) and remelted PE. The two samples were real-time aged, in a pure, distilled water bath at $40^{\circ} \mathrm{C}$ for 128 weeks. Again, at increasing aging times, the annealed sample showed increasing oxidation, with a maximum located at a subsurface level, while no oxidation was detected in the remelted PE (Figure 5). Upon testing the hip simulator wear rate of the real-time aged, annealed components, the authors also observed that it was higher than the literature reported values of other contemporary highly crosslinked UHMWPEs.

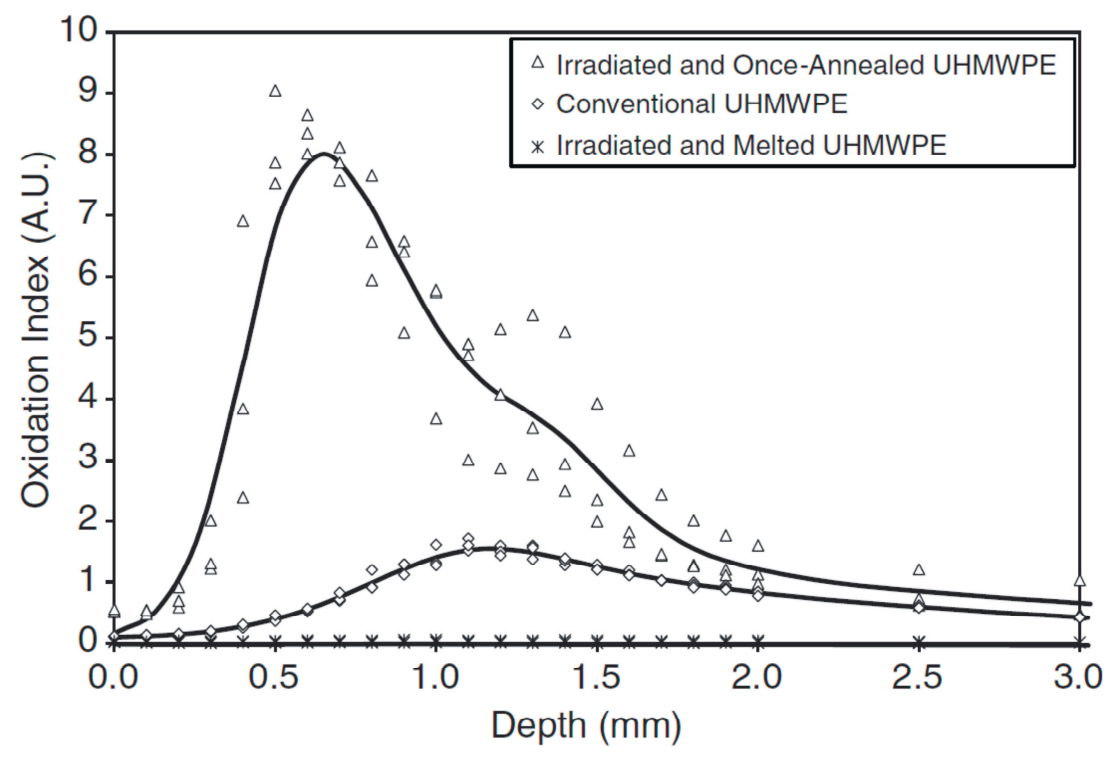

Figure 5. Oxidation profiles of conventional UHMWPE (gamma-inert sterilized, 25-40 kGy), irradiated and once-annealed UHMWPE (CrossfireTM Stryker-Howmedica-Osteonics; Rutherford, NJ, USA), and irradiated and melted UHMWPE (DurasulTM Zimmer, formerly Centerpulse; Austin, TX, USA) after 128 weeks of real-time aqueous aging at $40{ }^{\circ} \mathrm{C}$. Reproduced with permission from [71].

Collier et al. in an extensive study that compared the physical and mechanical properties of commercial, 1st generation crosslinked polyethylenes from six orthopaedic manufacturers [72], also concluded that, again, crosslinked/annealed PE was prone to oxidation, following accelerated aging, while all of the tested crosslinked/remelted materials showed oxidation resistance equal to that of never-irradiated polyethylene before and after accelerated aging and thus have the potential to remain relatively unaffected by oxidation throughout their duration in vivo.

Most of the aforementioned studies attributed the differences in the oxidative stability between remelted and annealed crosslinked polyethylenes to that a thermal treatment above the melting temperature (remelting), leads to a complete melting of the polymer crystallites, hereby allowing termination of the radicals trapped in the crystalline phase and thus brings the amount of residual radicals to undetectable levels [71,73]. Conversely, annealing just below the melting temperature 
leaves a measurable amount of free radicals in the polymer matrix, that can react with oxygen over time, thus triggering the oxidation cascade [61].

\subsection{Clinical Outcomes and Retrieval Studies}

Several clinical studies have reported superior in vivo wear performance of highly crosslinked PE, compared to conventional polyethylene in hip replacements [74-87], most of which were included in an extensive, systematic review of the clinical outcomes of 1st generation crosslinked polyethylene appearing at the beginning of the present decade [88]. Conversely, very few studies exist on the clinical performances of highly crosslinked polyethylene in the knee [89-91], partly because of a more limited introduction of this material in knee arthroplasty, due to recurrent concerns on its suitability, as a result of the loss in mechanical properties with increasing doses of radiation [88] and partly because of the lack of validated methods of determining the wear and damage rate of these components in vivo [56].

A number of retrieval studies have also reported on the chemical, physical and mechanical properties of these highly crosslinked PE following in vivo aging. According to predictions of in vitro studies, oxidation of the highly crosslinked/annealed formulation was reported by a number of authors [92-95]. Highly variable oxidation levels were measured in all the retrieval groups included in these studies, although none of the components had been explanted specifically for polyethylene wear. All studies agreed that the highest oxidation is generally measured at the superior rim of the component and not at the bearing surfaces and it was postulated that this occurs because of the greater exposure of the rim area, compared to the bearing area, to molecular oxygen in the in vivo environment [96].

On the other hand, failures of some specific designs of highly crosslinked/remelted have also been described in the literature [97,98]. Rim fractures have been observed in some components and have been attributed to the combination of reduced fatigue resistance induced by irradiation and remelting, with malpositioning and with particularly demanding designs, in terms of stress concentration [97].

As already mentioned, crosslinked/remelted polyethylenes did not contain free radicals at the time of implantation and were expected to be stable to oxidation. Unexpectedly, some recent literature studies reported that measurable levels of oxidation were observed in some retrievals [99-104]. Two concurrent causes have been tentatively identified to explain such a surprising phenomenon. One is that the cyclic loading to which the components are exposed during in vivo service might have generated free radicals, initiating mechano-oxidation [24,102]. The other involves the lipids absorbed in vivo from the synovial fluid [105]. Oral et al. [106] demonstrated that, under accelerated aging conditions, squalene, a precursor in cholesterol synthesis, has the potential to accelerate oxidation in radical-free, irradiated and melted UHMWPE.

Although the clinical significance of such adverse behaviors of the 1st generation highly crosslinked PE is still under debate, their occurrence stimulated the research of alternative polyethylene formulations to overcome the observed drawbacks.

\section{2nd Generation Highly Crosslinked Polyethylene}

\subsection{The Need for a 2nd Generation Crosslinked Polyethylene}

The rationale at the basis of a new generation of highly crosslinked polyethylene was to maintain the superior wear resistance demonstrated by the 1st generation crosslinked PE, while also retaining the mechanical properties and fatigue resistance of the uncrosslinked material and ensuring stable properties, thus oxidative stability, over time.

\subsection{Sequentially Irradiated and Annealed Highly Crosslinked Polyethylene}

As discussed in the previous paragraph, annealing below the melting temperature preserves most of the original UHMWPE microstructure. Highly crosslinked/annealed PE had been demonstrated to retain mechanical properties and fatigue resistance similar to conventional, gamma-nitrogen sterilized 
(but unoxidized) material; however, the presence of free radicals in the latter leaves the polyethylene exposed to oxidation [62]. Dumbleton and coworkers [107] proposed that it might have been possible to create a highly crosslinked PE by using a sequential irradiation and annealing process. Since a high ( $\geq 100 \mathrm{kGy}$ ) radiation dose creates many crosslinks that reduce the chain mobility, preventing an efficient elimination of the free radicals by annealing, they postulated that by using a low radiation dose (30 kGy), hereby spacing the crosslinks wider and providing higher chain mobility, annealing would have been more efficient in eliminating free radicals. High crosslinking levels could still be obtained by sequentially repeating the irradiation and annealing steps so that the polyethylene cumulatively receives a high dose of radiation (approx. $90 \mathrm{kGy}$ ).

This 2nd generation crosslinked PE (X3 ${ }^{\mathrm{TM}}$, Stryker Orthopaedics, Mahwah, NJ, USA) was terminally sterilized with gas plasma, so as to avoid the introduction of more free radicals with sterilization. Literature studies reported similar or only slightly reduced mechanical and fatigue properties compared to conventional PE $[62,67,107,108]$ and superior wear resistance in vitro $[67,107-109]$ and in vivo $[110,111]$. However, incomplete melting following irradiation leaves a low but measurable amount of free radicals in the material $[107,109]$, that was demonstrated to oxidize in vivo [100,103,112-114]. Although most studies agreed that the measured levels of oxidation were generally low, in particular much lower than those reported for the 1st generation once-annealed highly crosslinked PE [100], and were not associated with a decline in the clinical performance of the sequentially annealed PE [113], observations of pitting and substantial material loss as well as subsurface white banding and cracking were also reported in a knee retrievals study [114]. More investigations and longer follow-up are therefore necessary to assess the overall in vivo performance of this type of 2 nd generation highly crosslinked PE.

\subsection{Antioxidants: The New frontier}

An alternative approach to the 2nd generation highly crosslinked polyethylene involves the addition of an anti-oxidant stabilizer, in order to efficiently inhibit the oxidative degradation, without the need for a thermal treatment of the irradiated polyethylene, so as to preserve the original morphology, mechanical properties and fatigue resistance [115]. Although this is a very common approach to stabilize polyolefins against oxidation [116], the addiction of additives to biomedical UHMWPE had created concerns related to their biocompatibility for a long time. The first scientific papers and patents mentioning the possibility of using vitamin $\mathrm{E}$ ( $\alpha$-tocopherol) as a biocompatible stabilizer for UHMWPE [18,117] and exploring the subject are dated back to the late 1990s and onwards [118-120], but the first vitamin E-stabilized UHMWPE did not appear on the orthopedic market before 2007 [121,122]. Since then, though, a number of studies have investigated the performances of crosslinked UHMWPE incorporating vitamin E [115,121-123], at the moment by far the most used, and other stabilizers [124-128].

Two methods are currently used to incorporate vitamin E into UHMWPE [5,115]. One involves blending of vitamin E with UHMWPE powder before consolidation and radiation crosslinking [121]. The presence of vitamin E, a radical scavenger, in UHMWPE during irradiation protects the polymer from oxidation [118,129-131] but reduces the efficiency of crosslinking [120,132]; therefore, the balance between the vitamin E concentration and the radiation dose must be optimized to obtain a simultaneously wear- and oxidation-resistant UHMWPE [133]. The alternative method is the diffusion of vitamin E into UHMWPE after radiation crosslinking [122]. The crosslinking efficiency of UHMWPE is not adversely affected by this method, but a homogenization step is required after incorporation to obtain adequate antioxidant concentration throughout the implants [134].

\subsection{Mechanical Properties, Oxidation Stability and Wear Performances}

Several studies have investigated the mechanical properties of both formulations of vitamin $\mathrm{E}$ stabilized PE. No significant differences in the static mechanical properties, nor in the fatigue crack propagation resistance have been observed when comparing virgin UHMWPE with blends containing up to 5000 ppm of vitamin E [118,135]. Conversely, it has been demonstrated that highly crosslinked 
vitamin E-stabilized UHMWPE exhibits improved material properties compared to 1st generation highly crosslinked PE. For example, vitamin E-doped 100-kGy irradiated UHMWPE demonstrated a 58\% improvement in fatigue strength compared to irradiated and melted UHMWPE [136], attributed to the avoidance of the loss of crystallinity during post-irradiation melting. Moreover, the ultimate strength, yield strength, elongation at break, and fatigue resistance of crosslinked vitamin E-stabilized UHMWPE were significantly higher than that of $100 \mathrm{kGy}$-irradiated and melted UHMWPE [137].

In addition, Vitamin E-stabilized PE has demonstrated superior oxidation stability under a variety of accelerated aging conditions. For example, blends of UHMWPE with 500, 1000 and 5000 ppm of vitamin $\mathrm{E}$, gamma irradiated to doses up to $100 \mathrm{kGy}$ were found to be more oxidatively stable than virgin, unirradiated UHMWPE, following accelerated aging at $90{ }^{\circ} \mathrm{C}$ in air [129]. Oral et al. [136] showed that vitamin E-doped, irradiated UHMWPEs developed significantly lower oxidation levels compared to 100-kGy irradiated UHMWPE after 5 weeks of accelerated aging at $80{ }^{\circ} \mathrm{C}$ in air, while Kurtz and coworkers [133] found that blending PE with doses of vitamin E as low as 125 ppm was sufficient to avoid oxidation and maintain baseline mechanical and chemical properties, after irradiation up to $75 \mathrm{kGy}$, through two weeks of accelerated aging, according to ASTM F 2003 (i.e., $70{ }^{\circ} \mathrm{C}$ and 5 atm oxygen) (Figure 6).
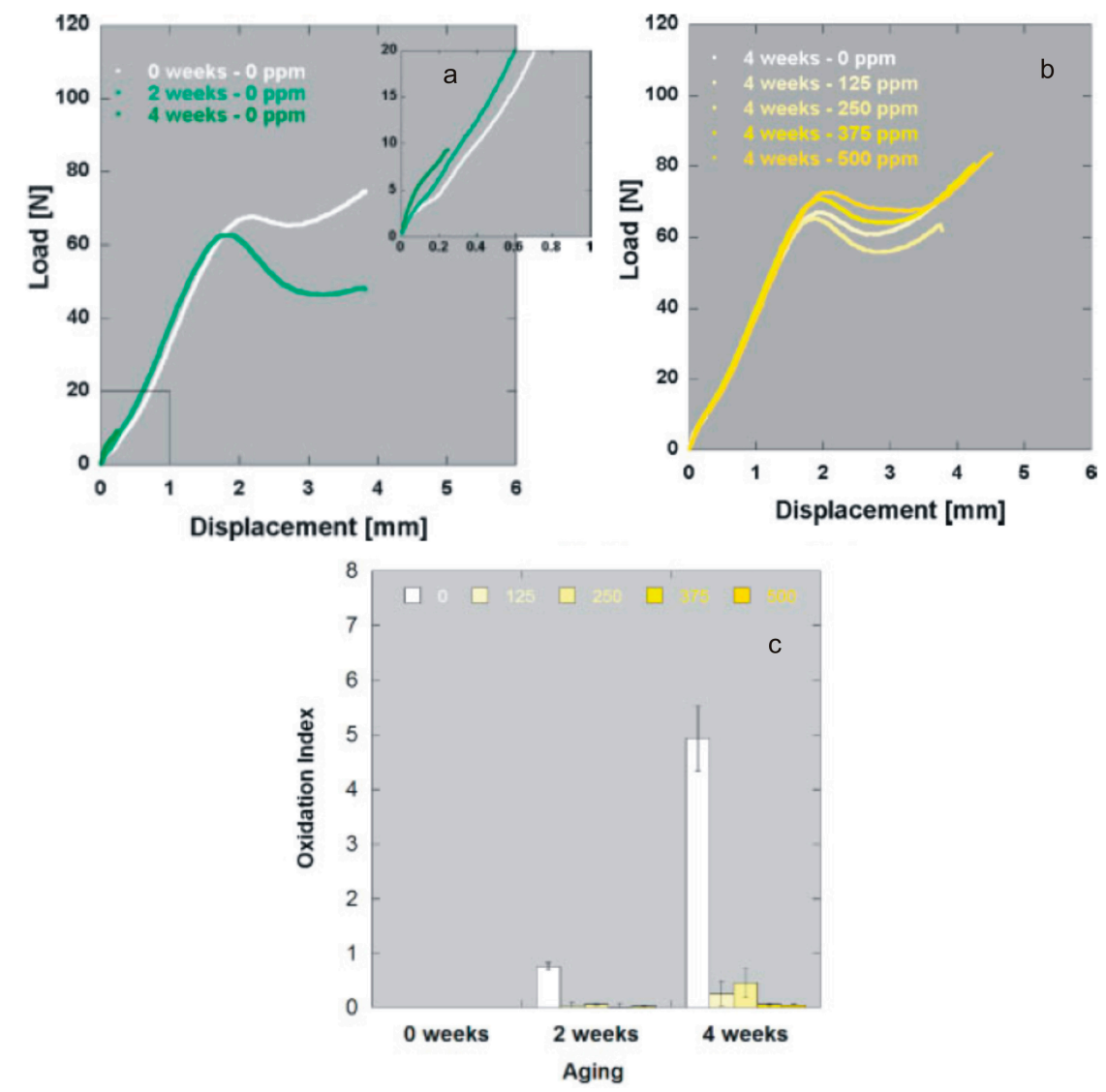

Figure 6. (a) Small punch curves of virgin UHMWPE irradiated at $75 \mathrm{kGy}$ in air: control and aged 2/4 weeks (ASTM F2003-00); (b) Small punch curves of UHMWPE blended with increasing concentrations (0-500 ppm) of vitamin E, irradiated at $75 \mathrm{kGy}$ in air and aged 4 weeks; (c) Oxidation indexes of UHMWPE blended with increasing concentrations of vitamin E (0-500 ppm), irradiated at $75 \mathrm{kGy}$ in air and aged 2/4 weeks. Adapted from [133], with permission.

The wear resistance of this 2nd generation highly crosslinked formulation has been extensively tested in several in vitro experiments, under a variety of challenging conditions, and has been 
compared to conventional and 1st generation highly crosslinked formulations before and after both accelerated and shelf-aging.

In a POD wear test, highly crosslinked Vitamin E-doped PE exhibited comparable wear rates to 1st generation highly crosslinked PE irradiated to the same dose [136], while it demonstrated a 4-fold to 10-fold decrease, respectively, from that of conventional UHMWPE in a hip simulator experiment with and without the addition of third-body particles [137].

Bellare et al. [138] compared the wear rates of vitamin E blended (1000 and 5000 ppm) vs. virgin UHMWPE, gamma irradiated to 30 and $100 \mathrm{kGy}$, before and after shelf aging for two years. The samples were also characterized for physical properties and crosslinking density: it was found that the crosslinking density increases with the radiation dose, but decreases with the vitamin $\mathrm{E}$ content. This was not surprising, as it is known that vitamin E, as a radical scavenger, can inhibit the crosslinking reactions [19]. Accordingly, the wear rates of the vitamin E containing samples were comparatively higher than that of virgin PE irradiated to the same dose, but lower than that of unirradiated PE. Conversely, after two years of shelf aging, virgin, irradiated, UHMWPE showed high oxidation levels, while vitamin $\mathrm{E}$, as expected, proved to be very effective in retarding oxidation.

Similarly, while comparing the wear behavior of standard, unirradiated PE to that of two formulations of crosslinked polyethylene, with and without vitamin E (1000 ppm), both irradiated to $70 \mathrm{kGy}$, Affatato et al. [139] found that the vitamin E blended PE exhibited a much lower wear than conventional ultra-high molecular weight polyethylene, but wore more than the traditional crosslinked polyethylene. Again, this was correlated to the lower crosslinking density induced by the same radiation dose in the presence of vitamin $E$.

These observations suggest that, if vitamin $\mathrm{E}$ is necessary to avoid oxidation, then the radiation dose must be optimized in order to obtain enough crosslinking density to preserve the wear resistance of unstabilized, crosslinked PE.

Given the concerns mentioned above on the use of 1st generation highly crosslinked PE in knee arthroplasty, the vitamin E crosslinked formulations represented an attractive alternative, in particular in this application. For this reason, many experimental studies investigated the performance of vitamin E stabilized PE for use in the knee with promising results. For example, while comparing the wear rate of two designs (cruciate-retaining and posterior-stabilized) of highly crosslinked UHMWPE doped with vitamin $\mathrm{E}$ to that of $\gamma$-inert-sterilized direct compression-molded UHMWPE, Haider and coworkers [140] found that the former exhibited up to $86 \%$ reduction in wear for both designs.

In another knee simulator experiment, UHMWPE blended with $1000 \mathrm{ppm}$ of vitamin $\mathrm{E}$ and radiation sterilized with $30 \pm 2 \mathrm{kGy}$, was artificially aged according to ASTM F2003-2 and tested for 5 million cycle without showing structural failures, as conventional PE did under similar conditions [141]. Similarly, vitamin E-stabilized highly crosslinked components tested after accelerated aging, in comparison to standard, unaged, UHMWPE, demonstrated a 57\% reduction in wear [142].

Teramura and coworkers [143] evaluated the wear behavior of direct compression molded tibial components, made of virgin and vitamin E blended (3000 ppm) UHMWPE. The components were gamma sterilized in air (ca. $25 \mathrm{kGy}$ ) and aged at $80^{\circ} \mathrm{C}$ in air for 23 days. It was demonstrated that the wear behavior of the vitamin E-containing UHMWPE was not significantly affected by aging and showed a 12-fold reduction, compared to that of the aged virgin UHMWPE. The wear debris particles were also evaluated for shape and size and no significant differences were observed between the two materials.

\subsection{The Effects of Vitamin E on UHMWPE Wear Debris}

Bladen et al. [144] demonstrated, as well, that particles generated by UHMWPE in a pin-on-plate wear simulator with and without VE were not significantly different in size distribution. They also investigated the biological activity of particles containing doses of vitamin E up to $30,000 \mathrm{ppm}$, and found that the vitamin E-containing particles secreted much lower levels of osteolytic mediators, 
tumor necrosis factor-alpha and interleukin, than particles of virgin UHMWPE at comparable volume doses.

To investigate the effects of particulate debris in vivo, Bichara et al. [145] compared the effect of clinically-relevant sized particulate debris from a crosslinked vitamin E-doped (8000 ppm) vs. a crosslinked/remelted UHMWPE bearing component in a murine calvarial bone model. A statistically significant difference in the amount of fibrous tissue was observed between the two materials, with virgin UHMWPE wear particles inducing the greatest amount of inflammatory tissue.

In addition, it has been shown that vitamin E may also exert some antibacterial activity [146-148]. This is likely due to differences in the surface hydrophilicity between virgin and vitamin E-stabilized polyethylene that in turn results in slightly different protein adhesion and biofilm formation.

\subsection{Clinical Outcomes and Retrieval Studies}

Literature reports on the clinical outcome of vitamin E stabilized PE are still quite limited in number, but their results are overall promising.

One recent study [149] comparing vitamin E-blended crosslinked polyethylene and conventional gamma-inert sterilized at three years follow up, demonstrated that the femoral head penetration was significantly lower for vitamin E-blended HXLPE and similar to that reported for 1st generation HXLPE. Also, no specific complications related to the material were reported in the short-term.

Prospective studies at two to three years follow-up demonstrated no significant differences in femoral head penetration rates between vitamin E doped and virgin highly crosslinked liners [150-152].

However, one study reporting head penetration into vitamin E doped highly crosslinked liners at five years demonstrated less wear compared to that previously reported for 1st generation highly crosslinked PE, at the same interval of five years. Further, the study demonstrated that, after settling of the liners in the early period, no significant head penetration occurred from two- to five-year follow-up and the authors remarked that, overall, the wear observed in the study was well below that at which osteolysis becomes a serious concern [153].

Rowell et al. [154] analyzed 15 surgically retrieved vitamin E-stabilized crosslinked UHMWPE liners to assess their oxidative stability, extent of lipid absorption in vivo, free radical content, hydroperoxide index and extent of visible wear damage after in vivo service (0.1-36.6 months). Their results evidenced promising results, in terms of oxidative resistance and absence of significant surface damage, while also suggesting long-term stability through a reduction in free radical content over time and lack of oxidation after ex vivo aging in air.

Similarly, Currier et al. [155] analyzed 25 antioxidant containing polyethylene tibial insert retrievals, including one formulation with an antioxidant other than vitamin $\mathrm{E}$, with in vivo time of $0-3$ years. All of the antioxidant materials appeared to be effective at minimizing oxidation over the in vivo period of the study. In addition, the authors speculated that the absence of subsurface peak oxidation suggest that antioxidant PE could be successful in preventing oxidation-mediated fatigue.

\section{Conclusions}

UHMWPE remains the most commonly used bearing material in total joint arthroplasty due to its long and relatively successful history. However, UHMWPE is a complex material and its mechanical and tribological behavior is strongly dependent on the morphology and chemical alterations induced by processing conditions, such as sterilization using ionizing radiation or crosslinking. The need for increasing the life expectancy of the implants, in order to meet the demand in younger and active patients, has led to a considerable evolution in the manufacturing of the UHMWPE orthopedic devices over the last few decades. From gamma-air sterilized "historical" polyethylenes, to the first and second generation of highly crosslinked materials, the wear resistance, mechanical properties and overall performances of the UHMWPE biomaterials have greatly improved, as has been extensively reported in the literature. Advances in the sterilization techniques have enabled a substantial reduction of the oxidative degradation experienced by "historical" implants, greatly lowering the incidence of 
wear-induced osteolysis and early mechanical failures. First generation crosslinked PE has further reduced wear, but at the expenses of fatigue resistance and/or oxidative stability, while 2nd generation crosslinked PE has been introduced to overcome the latter drawback and, overall, it has shown promising, yet early results, despite some issues regarding the oxidative stability of the sequentially irradiated and annealed PE.

Nevertheless, the clinical outcome of some of the newest formulations is still largely unexplored. It is therefore of paramount importance to ensure a close, continuous monitoring of the clinical performances of the contemporary UHMWPE biomaterials.

Conflicts of Interest: The authors declare no conflict of interest.

\section{References}

1. Kurtz, S.M. The Origins of UHMWPE in Total Hip Arthroplasty. In UHMWPE Biomaterials Handbook; Elsevier: Amsterdam, The Netherlands, 2016; pp. 33-44. [CrossRef]

2. Kurtz, S.M.; Ong, K.; Lau, E.; Mowat, F.; Halpern, M. Projections of primary and revision hip and knee arthroplasty in the United States from 2005 to 2030. J. Bone Jt. Surg. Ser. A 2007, 89. [CrossRef]

3. Kurtz, S.M.; Ong, K.L.; Lau, E.; Widmer, M.; Maravic, M.; Gómez-Barrena, E.; de Pina, M.d.F.; Manno, V.; Torre, M.; Walter, W.L.; et al. International survey of primary and revision total knee replacement. Int. Orthop. 2011, 35, 1783-1789. [CrossRef] [PubMed]

4. Kurtz, S.M.; Lau, E.; Ong, K.; Zhao, K.; Kelly, M.; Bozic, K.J. Future young patient demand for primary and revision joint replacement: National projections from 2010 to 2030. Clin. Orthop. Relat. Res. 2009, 467. [CrossRef] [PubMed]

5. Sobieraj, M.C.; Rimnac, C.M. Ultra high molecular weight polyethylene: Mechanics, morphology, and clinical behavior. J. Mech. Behav. Biomed. Mater. 2009, 2, 433-443. [CrossRef] [PubMed]

6. Brostow, W.; Hagg Lobland, H.E. Spatial structures of macromolecules and associated properties. In Materials: Introduction and Applications; John Wiley \& Sons: New York, NY, USA, 2017; pp. 178-183.

7. Barron, D.; Birkinshaw, C. Ultra-high molecular weight polyethylene-Evidence for a three-phase morphology. Polymer 2008, 49, 3111-3115. [CrossRef]

8. Kurtz, S.M. From Ethylene Gas to UHMWPE Component: The Process of Producing Orthopedic Implants. In UHMWPE Biomaterials Handbook; Elsevier: Amsterdam, The Netherlands, 2016; pp. 7-20. [CrossRef]

9. Deplancke, T.; Lame, O.; Rousset, F.; Seguela, R.; Vigier, G. Mechanisms of Chain Reentanglement during the Sintering of UHMWPE Nascent Powder: Effect of Molecular Weight. Macromolecules 2015, 48, 5328-5338. [CrossRef]

10. Kurtz, S.M.; Zagorski, M. Packaging and Sterilization of UHMWPE. In UHMWPE Biomaterials Handbook; Elsevier: Amsterdam, The Netherlands, 2016; pp. 21-32. [CrossRef]

11. Costa, L.; Bracco, P.; del Prever, E.M.B.; Kurtz, S.M.; Gallinaro, P. Oxidation and oxidation potential in contemporary packaging for polyethylene total joint replacement components. J. Biomed. Mater. Res. Part B Appl. Biomater. 2006, 78, 20-26. [CrossRef] [PubMed]

12. Streicher, R.M. Ionizing irradiation for sterilization and modification of high molecular weight polyethylenes. Plast. Rubber Process. Appl. 1988, 10, 221-229.

13. Premnath, V.; Bellare, A.; Merrill, E.W.W.; Jasty, M.; Harris, W.H.H. Molecular rearrangements in ultra high molecular weight polyethylene after irradiation and long-term storage in air. Polymer 1999, 40, 2215-2229. [CrossRef]

14. Bracco, P.; Brunella, V.; Luda, M.P.; Brach del Prever, E.M.; Zanetti, M.; Costa, L. Oxidation behaviour in prosthetic UHMWPE components sterilised with high-energy radiation in the presence of oxygen. Polym. Degrad. Stab. 2006, 91. [CrossRef]

15. Rimnac, C.M.; Klein, R.W.; Betts, F.; Wright, T.M. Post-irradiation aging of ultra-high molecular weight polyethylene. J. Bone Jt. Surg. Am. 1994, 76, 1052-1056. [CrossRef]

16. Sutula, L.C.; Collier, J.P.; Saum, K.A.; Currier, B.H.; Currier, J.H.; Sanford, W.M.; Mayor, M.B.; Wooding, R.E.; Sperling, D.K.; Williams, I.R. The Otto Aufranc Award: Impact of gamma sterilization on clinical performance of polyethelene in the hip. Clin. Orthop. Relat. Res. 1995, 319, 28-40. [CrossRef] 
17. Costa, L.; Luda, M.P.P.; Trossarelli, L.; Brach del Prever, E.M.; Crova, M.; Gallinaro, P. Oxidation in orthopaedic UHMWPE sterilized by gamma-radiation and ethylene oxide. Biomaterials 1998, 19, 659-668. [CrossRef]

18. Costa, L.; Luda, M.P.P.; Trossarelli, L.; Brach del Prever, E.M.; Crova, M.; Gallinaro, P. In vivo UHMWPE biodegradation of retrieved prosthesis. Biomaterials 1998, 19, 1371-1385. [CrossRef]

19. Costa, L.; Bracco, P. Mechanisms of Cross-Linking, Oxidative Degradation, and Stabilization of UHMWPE. In UHMWPE Biomaterials Handbook: Ultra High Molecular Weight Polyethylene in Total Joint Replacement and Medical Devices, 3rd ed.; Kurtz, S.M., Ed.; Elsevier Inc.: Amsterdam, The Netherlands, 2015; pp. 467-487. [CrossRef]

20. Goldman, M.; Gronsky, R.; Ranganathan, R.; Pruitt, L. The effects of gamma radiation sterilization and ageing on the structure and morphology of medical grade ultra high molecular weight polyethylene. Polymer 1996, 37, 2909-2913. [CrossRef]

21. Kurth, M.; Eyerer, P.; Ascherl, R.; Dittel, K.; Holz, U. An Evaluation of Retrieved UHMWPE Hip Joint Cups. J. Biomater. Appl. 1988, 3, 33-51. [CrossRef] [PubMed]

22. Lee, K.-Y.; Lee, K.H. Wear of shelf-aged UHMWPE acetabular liners. Wear 1999, 225-229, 728-733. [CrossRef]

23. Regis, M.; Bracco, P.; Giorgini, L.; Fusi, S.; Pria, P.D.; Costa, L.L.; Schmid, C. Correlation between in vivo stresses and oxidation of UHMWPE in total hip arthroplasty. J. Mater. Sci. Mater. Med. 2014, 25. [CrossRef] [PubMed]

24. Medel, F.; Kurtz, S.M.; MacDonald, D.; Pascual, F.J.; Puértolas, J.A. Does Cyclic Stress Play a Role in Highly Crosslinked Polyethylene Oxidation? Clin. Orthop. Relat. Res. 2015, 473, 1022-1029. [CrossRef] [PubMed]

25. Brostow, W.; Hagg Lobland, H.E.; Narkis, M. Sliding wear, viscoelasticity, and brittleness of polymers. J. Mater. Res. 2006, 21. [CrossRef]

26. Brostow, W.; Hagg Lobland, H.E. Survey of relations of chemical constituents in polymer-based materials with brittleness and its associated properties. Chem. Chem. Technol. 2016, 10, 595-601. [CrossRef]

27. Edidin, A.A.; Jewett, C.W.; Kalinowski, A.; Kwarteng, K.; Kurtz, S.M. Degradation of mechanical behavior in UHMWPE after natural and accelerated aging. Biomaterials 2000, 21, 1451-1460. [CrossRef]

28. Edidin, A.A.; Herr, M.P.; Villarraga, M.L.; Muth, J.; Yau, S.S.; Kurtz, S.M. Accelerated aging studies of UHMWPE. I. Effect of resin, processing, and radiation environment on resistance to mechanical degradation. J. Biomed. Mater. Res. 2002, 61, 312-322. [CrossRef] [PubMed]

29. Collier, J.P.; Sperling, D.K.; Currier, J.H.; Sutula, L.C.; Saum, K.A.; Mayor, M.B. Impact of gamma sterilization on clinical performance of polyethylene in the knee. J. Arthroplast. 1996, 11, 377-389. [CrossRef]

30. Baker, D.A.; Hastings, R.S.; Pruitt, L. Compression and tension fatigue resistance of medical grade ultra high molecular weight polyethylene: The effect of morphology, sterilization, aging and temperature. Polymer 2000, 41, 795-808. [CrossRef]

31. White, S.E.; Paxson, R.D.; Tanner, M.G.; Whiteside, L.A. Effects of sterilization on wear in total knee arthroplasty. Clin. Orthop. Relat. Res. 1996, 331, 164-171. [CrossRef]

32. Collier, M.B.; Engh, C.A., Jr.; McAuley, J.P.; Engh, G.A. Factors associated with the loss of thickness of polyethylene tibial bearings after knee arthroplasty. J. Bone Jt. Surg. Ser. A 2007, 89. [CrossRef]

33. McKellop, H.; Shen, F.W.; Lu, B.; Campbell, P.; Salovey, R. Effect of sterilization method and other modifications on the wear resistance of acetabular cups made of ultra-high molecular weight polyethylene. A hip-simulator study. J. Bone Jt. Surg. Ser. A 2000, 82, 1708-1725. [CrossRef]

34. Young, S.K.; Keller, T.S.; Greer, K.W.; Gorhan, M.C. Wear testing of UHMWPE tibial components: Influence of oxidation. J. Tribol. 2000, 122. [CrossRef]

35. Brostow, W.; Hagg Lobland, H.E. Wear. In Materials: Introduction and Applications; John Wiley \& Sons: New York, NY, USA, 2017; pp. 418-419.

36. Endo, M.; Tipper, J.L.; Barton, D.C.; Stone, M.H.; Ingham, E.; Fisher, J. Comparison of wear, wear debris and functional biological activity of moderately crosslinked and non-crosslinked polyethylenes in hip prostheses. Proc. Inst. Mech. Eng. Part H J. Eng. Med. 2002, 216, 111-122. [CrossRef] [PubMed]

37. Wang, A.; Essner, A.; Cooper, J. The Clinical Relevance of Hip Simulator Testing of High Performance Implants. Semin. Arthroplast. 2006, 17, 49-55. [CrossRef]

38. Affatato, S.; Bordini, B.; Fagnano, C.; Taddei, P.; Tinti, A.; Toni, A. Effects of the sterilisation method on the wear of UHMWPE acetabular cups tested in a hip joint simulator. Biomaterials 2002, 23, 1439-1446. [CrossRef] 
39. Affatato, S.; Bersaglia, G.; Foltran, I.; Taddei, P.; Fini, G.; Toni, A. The performance of gamma- and EtO-sterilised UHWMPE acetabular cups tested under severe simulator conditions. Part 1: Role of the third-body wear process. Biomaterials 2002, 23, 4839-4846. [CrossRef]

40. McKellop, H.A.; Shen, F.W.; Campbell, P.; Ota, T. Effect of molecular weight, calcium stearate, and sterilization methods on the wear of ultra high molecular weight polyethylene acetabular cups in a hip joint simulator. J. Orthop. Res. 1999, 17, 329-339. [CrossRef] [PubMed]

41. McKellop, H.; Shen, F.W.; Lu, B.; Campbell, P.; Salovey, R. Development of an extremely wear-resistant ultra high molecular weight polyethylene for total hip replacements. J. Orthop. Res. Off. Publ. Orthop. Res. Soc. 1999, 17, 157-167. [CrossRef] [PubMed]

42. Muratoglu, O.K.; Bragdon, C.R.; O'Connor, D.; Jasty, M.; Harris, W.H.; Gul, R.; McGarry, F. Unified wear model for highly crosslinked ultra-high molecular weight polyethylenes (UHMWPE). Biomaterials 1999, 20, 1463-1470. [CrossRef]

43. Kurtz, S.M.; Rimnac, C.M.; Hozack, W.J.; Turner, J.; Marcolongo, M.; Goldberg, V.M.; Kraay, M.J.; Edidin, A.A. In vivo degradation of polyethylene liners after gamma sterilization in air. J. Bone Jt. Surg. Ser. A 2005, 87, 815. [CrossRef]

44. Streicher, R.M. Sterilization and long-term aging of medical-grade UHMWPE. Radiat. Phys. Chem. 1995, 46, 893-896. [CrossRef]

45. Goosen, J.H.M.; Verheyen, C.C.P.M.; Kollen, B.J.; Tulp, N.J.A. In vivo wear reduction of argon compared to air sterilized UHMW-polyethylene liners. Arch. Orthop. Trauma Surg. 2009, 129, 879-885. [CrossRef] [PubMed]

46. Kurtz, S.M.; Muratoglu, O.K.; Evans, M.; Edidin, A.A. Advances in the processing, sterilization, and crosslinking of ultra- high molecular weight polyethylene for total joint arthroplasty. Biomaterials 1999, 20, 1659-1688. [CrossRef]

47. Lu, S.; Orr, J.F.; Buchanan, F.J. The influence of inert packaging on the shelf ageing of gamma-irradiation sterilised ultra-high molecular weight polyethylene. Biomaterials 2003, 24, 139-145. [CrossRef]

48. Currier, B.H.; Currier, J.H.; Mayor, M.B.; Lyford, K.A.; van Citters, D.W.; Collier, J.P. In Vivo Oxidation of $\gamma$-Barrier-Sterilized Ultra-High-Molecular-Weight Polyethylene Bearings. J. Arthroplast. 2007, 22, 721-731. [CrossRef] [PubMed]

49. Bracco, P.; del Prever, E.M.B.; Cannas, M.; Luda, M.P.; Costa, L. Oxidation behaviour in prosthetic UHMWPE components sterilised with high energy radiation in a low-oxygen environment. Polym. Degrad. Stab. 2006, 91, 2030-2038. [CrossRef]

50. Wang, A.; Essner, A.; Polineni, V.; Stark, C.; Dumbleton, J. Lubrication and wear of ultra-high molecular weight polyethylene in total joint replacements. Tribol. Int. 1998, 31, 17-33. [CrossRef]

51. Wang, A.; Sun, D.C.; Yau, S.-S.; Edwards, B.; Sokol, M.; Essner, A.; Polineni, V.K.; Stark, C.; Dumbleton, J.H. Orientation softening in the deformation and wear of ultra-high molecular weight polyethylene. Wear 1997, 203-204, 230-241. [CrossRef]

52. Wang, A. A unified theory of wear for ultra-high molecular weight polyethylene in multi-directional sliding. Wear 2001, 248, 38-47. [CrossRef]

53. Campbell, P.; Doom, P.; Dorey, F.; Amstutz, H.C. Wear and morphology of ultra-high molecular weight polyethylene wear particles from total hip replacements. Proc. Inst. Mech. Eng. Part H J. Eng. Med. 1996, 210, 167-174. [CrossRef] [PubMed]

54. McKellop, H.A.; Campbell, P.; Park, S.-H.; Schmalzried, T.P.; Grigoris, P.; Amstutz, H.C.; Sarmiento, A. The origin of submicron polyethylene wear debris in total hip arthroplasty. Clin. Orthop. Relat. Res. 1995, 311, 3-20.

55. Tipper, J.L.; Ingham, E.; Hailey, J.L.; Besong, A.A.; Fisher, J.; Wroblewski, B.M.; Stone, M.H. Quantitative analysis of polyethylene wear debris, wear rate and head damage in retrieved Charnley hip prostheses. J. Mater. Sci. Mater. Med. 2000, 11, 117-124. [CrossRef] [PubMed]

56. Muratoglu, O.K.; Bragdon, C.R. Highly Cross-Linked and Melted UHMWPE. In UHMWPE Biomaterials Handbook; Elsevier: Amsterdam, The Netherlands, 2016; pp. 264-273. [CrossRef]

57. Bracco, P.; Brunella, V.; Luda, M.P.; Zanetti, M.; Costa, L. Radiation-induced crosslinking of UHMWPE in the presence of co-agents: Chemical and mechanical characterisation. Polymer 2005, 46, 10648-10657. [CrossRef]

58. Lewis, G. Properties of crosslinked ultra-high-molecular-weight polyethylene. Biomaterials $2001,22$. [CrossRef] 
59. Gomoll, A.; Wanich, T.; Bellare, A. J-integral fracture toughness and tearing modulus measurement of radiation cross-linked UHMWPE. J. Orthop. Res. 2002, 20, 1152-1156. [CrossRef]

60. Baker, D.A.; Bellare, A.; Pruitt, L. The effects of degree of crosslinking on the fatigue crack initiation and propagation resistance of orthopedic-grade polyethylene. J. Biomed. Mater. Res. 2003, 66A, 146-154. [CrossRef] [PubMed]

61. Kurtz, S.M.; Manley, M.; Wang, A.; Taylor, S.; Dumbleton, J. Comparison of the properties of annealed crosslinked (Crossfire) and conventional polyethylene as hip bearing materials. Bull. Hosp. Jt. Dis. 2003, 61, 17-26.

62. Manley, M.T. Highly Cross-Linked and Annealed UHMWPE. In UHMWPE Biomaterials Handbook; Elsevier: Amsterdam, The Netherlands, 2016; pp. 274-292. [CrossRef]

63. Oral, E.; Malhi, A.; Muratoglu, O. Mechanisms of decrease in fatigue crack propagation resistance in irradiated and melted UHMWPE. Biomaterials 2006, 27, 917-925. [CrossRef] [PubMed]

64. Bistolfi, A.; Bellare, A. The relative effects of radiation crosslinking and type of counterface on the wear resistance of ultrahigh-molecular-weight polyethylene. Acta Biomater. 2011, 7, 3398-3403. [CrossRef] [PubMed]

65. Medel, F.J.; Peña, P.; Cegoñino, J.; Gómez-Barrena, E.; Puértolas, J.A. Comparative fatigue behavior and toughness of remelted and annealed highly crosslinked polyethylenes. J. Biomed. Mater. Res. Part B Appl. Biomater. 2007, 83B, 380-390. [CrossRef] [PubMed]

66. Ries, M.D.; Pruitt, L. Effect of cross-linking on the microstructure and mechanical properties of ultra-high molecular weight polyethylene. Clin. Orthop. Relat. Res. 2005, 440, 149-156. [CrossRef] [PubMed]

67. Atwood, S.A.; van Citters, D.W.; Patten, E.W.; Furmanski, J.; Ries, M.D.; Pruitt, L.A. Tradeoffs amongst fatigue, wear, and oxidation resistance of cross-linked ultra-high molecular weight polyethylene. J. Mech. Behav. Biomed. Mater. 2011, 4. [CrossRef] [PubMed]

68. Affatato, S.; Bersaglia, G.; Rocchi, M.; Taddei, P.; Fagnano, C.; Toni, A. Wear behaviour of cross-linked polyethylene assessed in vitro under severe conditions. Biomaterials 2005, 26, 3259-3267. [CrossRef] [PubMed]

69. Galvin, A.L.; Tipper, J.L.; Jennings, L.M.; Stone, M.H.; Jin, Z.M.; Ingham, E.; Fisher, J. Wear and biological activity of highly crosslinked polyethylene in the hip under low serum protein concentrations. Proc. Instit. Mech. Eng. Part H J. Eng. Med. 2007, 221, 1-10. [CrossRef] [PubMed]

70. Muratoglu, O.K.; Merrill, E.W.; Bragdon, C.R.; O'Connor, D.; Hoeffel, D.; Burroughs, B.; Jasty, M.; Harris, W.H. Effect of Radiation, Heat, and Aging on In Vitro Wear Resistance of Polyethylene. Clin. Orthop. Relat. Res. 2003, 417, 253-262.

71. Wannomae, K.K.; Christensen, S.D.; Freiberg, A.A.; Bhattacharyya, S.; Harris, W.H.; Muratoglu, O.K. The effect of real-time aging on the oxidation and wear of highly cross-linked UHMWPE acetabular liners. Biomaterials 2006, 27, 1980-1987. [CrossRef] [PubMed]

72. Collier, J.P.; Currier, B.H.; Kennedy, F.E.; Currier, J.H.; Timmins, G.S.; Jackson, S.K.; Brewer, R.L. Comparison of Cross-Linked Polyethylene Materials for Orthopaedic Applications. Clin. Orthop. Relat. Res. 2003, $289-304$. [CrossRef] [PubMed]

73. Muratoglu, O.K.; Bragdon, C.R.; O'Connor, D.O.; Jasty, M.; Harris, W.H. A novel method of cross-linking ultra-high-molecular-weight polyethylene to improve wear, reduce oxidation, and retain mechanical properties. J. Arthroplast. 2001, 16, 149-160. [CrossRef] [PubMed]

74. Geller, J.A.; Malchau, H.; Bragdon, C.; Greene, M.; Harris, W.H.; Freiberg, A.A. Large Diameter Femoral Heads on Highly Cross-linked Polyethylene. Clin. Orthop. Relat. Res. 2006, 447, 53-59. [CrossRef] [PubMed]

75. Röhrl, S.; Nivbrant, B.; Mingguo, L.; Hewitt, B. In Vivo Wear and Migration of Highly Cross-Linked Polyethylene Cups. J. Arthroplast. 2005, 20, 409-413. [CrossRef] [PubMed]

76. Manning, D.W.; Chiang, P.P.; Martell, J.M.; Galante, J.O.; Harris, W.H. In Vivo Comparative Wear Study of Traditional and Highly Cross-li.nked Polyethylene in Total Hip Arthroplasty. J. Arthroplast. 2005, 20, 880-886. [CrossRef] [PubMed]

77. Krushell, R.J.; Fingeroth, R.J.; Cushing, M.C. Early Femoral Head Penetration of a Highly Cross-Linked Polyethylene Liner vs a Conventional Polyethylene Liner. J. Arthroplast. 2005, 20, 73-76. [CrossRef] [PubMed]

78. D'Antonio, J.A.; Manley, M.T.; Capello, W.N.; Bierbaum, B.E.; Ramakrishnan, R.; Naughton, M.; Sutton, K. Five-year experience with Crossfire ${ }^{\circledR}$ highly cross-linked polyethylene. Clin. Orthop. Relat. Res. 2005. [CrossRef] 
79. Rajadhyaksha, A.D.; Brotea, C.; Cheung, Y.; Kuhn, C.; Ramakrishnan, R.; Zelicof, S.B. Five-Year Comparative Study of Highly Cross-Linked (Crossfire) and Traditional Polyethylene. J. Arthroplast. 2009, 24. [CrossRef] [PubMed]

80. Dorr, L.D.; Wan, Z.; Shahrdar, C.; Sirianni, L.; Boutary, M.; Yun, A. Clinical performance of a Durasul highly cross-linked polyethylene acetabular liner for total hip arthroplasty at five years. J. Bone Jt. Surg. Ser. A 2005, 87, 1816. [CrossRef]

81. Digas, G.; Karrholm, J.; Thanner, J.; Malchau, H.; Herberts, P. The Otto Aufranc Award: Highly Cross-linked Polyethylene in Total Hip Arthroplasty. Clin. Orthop. Relat. Res. 2004, 429, 6-16. [CrossRef]

82. Bragdon, C.R.; Doerner, M.; Martell, J.; Jarrett, B.; Palm, H.; Malchau, H. The 2012 John Charnley Award: Clinical Multicenter Studies of the Wear Performance of Highly Crosslinked Remelted Polyethylene in THA. Clin. Orthop. Relat. Res. 2013, 471, 393-402. [CrossRef] [PubMed]

83. Mutimer, J.; Devane, P.A.; Adams, K.; Horne, J.G. Highly Crosslinked Polyethylene Reduces Wear in Total Hip Arthroplasty at 5 Years. Clin. Orthop. Relat. Res. 2010, 468, 3228-3233. [CrossRef] [PubMed]

84. Engh, C.A., Jr.; Stepniewski, A.S.; Ginn, S.D.; Beykirch, S.E.; Sychterz-Terefenko, C.J.; Hopper, R.H., Jr.; Engh, C.A. A Randomized Prospective Evaluation of Outcomes After Total Hip Arthroplasty Using Cross-linked Marathon and Non-cross-linked Enduron Polyethylene Liners. J. Arthroplast. 2006, 21, 17-25. [CrossRef] [PubMed]

85. Garcia-Rey, E.; Garcia-Cimbrelo, E.; Cruz-Pardos, A.; Ortega-Chamarro, J. New polyethylenes in total hip replacement: A Prospective, Comparative Clinical Study of two Types of Liner. J. Bone Jt. Surg. Br. Vol. 2008, 90-B, 149-153. [CrossRef] [PubMed]

86. Glyn-Jones, S.; Thomas, G.E.R.; Garfjeld-Roberts, P.; Gundle, R.; Taylor, A.; McLardy-Smith, P.; Murray, D.W. The John Charnley Award: Highly Crosslinked Polyethylene in Total Hip Arthroplasty Decreases Long-term Wear: A Double-blind Randomized Trial. Clin. Orthop. Relat. Res. 2015, 473, 432-438. [CrossRef] [PubMed]

87. Atienza, C., Jr.; Maloney, W.J. Highly cross-linked polyethylene bearing surfaces in total hip arthroplasty. J. Surg. Orthop. Adv. 2008, 17, 27-33. [PubMed]

88. Kurtz, S.M.; Gawel, H.A.; Patel, J.D. History and Systematic Review of Wear and Osteolysis Outcomes for First-generation Highly Crosslinked Polyethylene. Clin. Orthop. Relat. Res. 2011, 469, 2262-2277. [CrossRef] [PubMed]

89. Minoda, Y.; Aihara, M.; Sakawa, A.; Fukuoka, S.; Hayakawa, K.; Tomita, M.; Umeda, N.; Ohzono, K. Comparison between highly cross-linked and conventional polyethylene in total knee arthroplasty. Knee 2009, 16, 348-351. [CrossRef] [PubMed]

90. Kim, Y.-H.; Park, J.-W. Comparison of Highly Cross-Linked and Conventional Polyethylene in Posterior Cruciate-Substituting Total Knee Arthroplasty in the Same Patients. J. Bone Jt. Surg.-Am. Vol. 2014, 96, 1807-1813. [CrossRef] [PubMed]

91. Hodrick, J.T.; Severson, E.P.; McAlister, D.S.; Dahl, B.; Hofmann, A.A. Highly Crosslinked Polyethylene is Safe for Use in Total Knee Arthroplasty. Clin. Orthop. Relat. Res. 2008, 466, 2806-2812. [CrossRef] [PubMed]

92. Wannomae, K.K.; Bhattacharyya, S.; Freiberg, A.; Estok, D.; Harris, W.H.; Muratoglu, O. In Vivo Oxidation of Retrieved Cross-linked Ultra-High-Molecular-Weight Polyethylene Acetabular Components with Residual Free Radicals. J. Arthroplast. 2006, 21, 1005-1011. [CrossRef] [PubMed]

93. Currier, B.H.; Currier, J.H.; Mayor, M.B.; Lyford, K.A.; Collier, J.P.; van Citters, D.W. Evaluation of oxidation and fatigue damage of retrieved crossfire polyethylene acetabular cups. J. Bone Jt. Surg. Ser. A 2007, 89. [CrossRef]

94. Kurtz, S.M.; Hozack, W.; Turner, J.; Purtill, J.; MacDonald, D.; Sharkey, P.; Parvizi, J.; Manley, M.; Rothman, R. Mechanical Properties of Retrieved Highly Cross-Linked Crossfire Liners After Short-Term Implantation. J. Arthroplast. 2005, 20, 840-849. [CrossRef] [PubMed]

95. Kurtz, S.M.; Austin, M.S.; Azzam, K.; Sharkey, P.F.; MacDonald, D.W.; Medel, F.J.; Hozack, W.J. Mechanical Properties, Oxidation, and Clinical Performance of Retrieved Highly Cross-Linked Crossfire Liners After Intermediate-Term Implantation. J. Arthroplast. 2010, 25, 614-623. [CrossRef] [PubMed]

96. Kurtz, S.M.; Hozack, W.J.; Purtill, J.J.; Marcolongo, M.; Kraay, M.J.; Goldberg, V.M.; Sharkey, P.F.; Parvizi, J.; Rimnac, C.M.; Edidin, A.A. Otto Aufranc award paper: Significance of in vivo degradation for polyethylene in total hip arthroplasty. Clin. Orthop. Relat. Res. 2006. [CrossRef] [PubMed]

97. Furmanski, J.; Anderson, M.; Bal, S.; Greenwald, A.S.; Halley, D.; Penenberg, B.; Ries, M.; Pruitt, L. Clinical fracture of cross-linked UHMWPE acetabular liners. Biomaterials 2009, 30, 5572-5582. [CrossRef] [PubMed] 
98. Tower, S.S.; Currier, J.H.; Currier, B.H.; Lyford, K.A.; van Citters, D.W.; Mayor, M.B. Rim cracking of the cross-linked longevity polyethylene acetabular liner after total hip arthroplasty. J. Bone Jt. Surg. Ser. A 2007, 89, 2212-2217. [CrossRef]

99. Currier, B.H.; Currier, J.H.; Franklin, K.J.; Mayor, M.B.; Reinitz, S.D.; van Citters, D.W. Comparison of Wear and Oxidation in Retrieved Conventional and Highly Cross-Linked UHMWPE Tibial Inserts. J. Arthroplast. 2015, 30, 2349-2353. [CrossRef] [PubMed]

100. Currier, B.H.; van Citters, D.W.; Currier, J.H.; Carlson, E.M.; Tibbo, M.E.; Collier, J.P. In vivo oxidation in retrieved highly crosslinked tibial inserts. J. Biomed. Mater. Res. Part B Appl. Biomater. 2012, 101B. [CrossRef]

101. Miura, Y.; Hasegawa, M.; Sudo, A.; Pezzotti, G.; Puppulin, L. In Vivo degradation of middle-term highly cross-linked and remelted polyethylene cups: Modification induced by creep, wear and oxidation. J. Mech. Behav. Biomed. Mater. 2015, 51, 13-24. [CrossRef] [PubMed]

102. Muratoglu, O.K.; Wannomae, K.K.; Rowell, S.L.; Micheli, B.R.; Malchau, H. Ex Vivo Stability Loss of Irradiated and Melted Ultra-High Molecular Weight Polyethylene. J. Bone Jt. Surg.-Am. Vol. 2010, 92, 2809-2816. [CrossRef] [PubMed]

103. Rowell, S.L.; Reyes, C.R.; Malchau, H.; Muratoglu, O.K. In Vivo Oxidative Stability Changes of Highly Cross-Linked Polyethylene Bearings: An Ex Vivo Investigation. J. Arthroplast. 2015, 30, 1828-1834. [CrossRef] [PubMed]

104. MacDonald, D.W.; Higgs, G.; Parvizi, J.; Klein, G.; Hartzband, M.; Levine, H.; Kraay, M.; Rimnac, C.M.; Kurtz, S.M. Oxidative properties and surface damage mechanisms of remelted highly crosslinked polyethylenes in total knee arthroplasty. Int. Orthop. 2013, 37, 611-615. [CrossRef] [PubMed]

105. Costa, L.; Bracco, P.; del Prever, E.B.; Luda, M.; Trossarelli, L. Analysis of products diffused into UHMWPE prosthetic components in vivo. Biomaterials 2001, 22, 307-315. [CrossRef]

106. Oral, E.; Ghali, B.W.; Neils, A.; Muratoglu, O.K. A new mechanism of oxidation in ultrahigh molecular weight polyethylene caused by squalene absorption. J. Biomed. Mater. Res. Part B Appl. Biomater. 2012, 100B, 742-751. [CrossRef] [PubMed]

107. Dumbleton, J.H.; D’Antonio, J.A.; Manley, M.T.; Capello, W.N.; Wang, A. The Basis for a Second-generation Highly Cross-linked UHMWPE. Clin. Orthop. Relat. Res. 2006, 453, 265-271. [CrossRef] [PubMed]

108. Wang, A.; Zeng, H.; Yau, S.-S.; Essner, A.; Manely, M.; Dumbleton, J. Wear, oxidation and mechanical properties of a sequentially irradiated and annealed UHMWPE in total joint replacement. J. Phys. D Appl. Phys. 2006, 39, 3213-3219. [CrossRef]

109. Wang, A.; Yau, S.-S.; Essner, A.; Herrera, L.; Manley, M.; Dumbleton, J. A Highly Crosslinked UHMWPE for CR and PS Total Knee Arthroplasties. J. Arthroplast. 2008, 23, 559-566. [CrossRef] [PubMed]

110. Sayeed, S.A.; Mont, M.A.; Costa, C.R.; Johnson, A.J.; Naziri, Q.; Bonutti, P.M.; Delanois, R.E. Early outcomes of sequentially cross-linked thin polyethylene liners with large diameter femoral heads in total hip arthroplasty. Bull. NYU Hosp. Jt. Dis. 2011, 69 (Suppl. 1), S90-S94. [PubMed]

111. D'Antonio, J.A.; Capello, W.N.; Ramakrishnan, R. Second-generation Annealed Highly Cross-linked Polyethylene Exhibits Low Wear. Clin. Orthop. Relat. Res. 2012, 470, 1696-1704. [CrossRef] [PubMed]

112. Reinitz, S.D.; Currier, B.H.; van Citters, D.W.; Levine, R.A.; Collier, J.P. Oxidation and other property changes of retrieved sequentially annealed UHMWPE acetabular and tibial bearings. J. Biomed. Mater. Res. Part B Appl. Biomater. 2015, 103, 578-586. [CrossRef] [PubMed]

113. Kurtz, S.M.; MacDonald, D.W.; Mont, M.A.; Parvizi, J.; Malkani, A.L.; Hozack, W. Retrieval Analysis of Sequentially Annealed Highly Crosslinked Polyethylene Used in Total Hip Arthroplasty. Clin. Orthop. Relat. Res. 2015, 473, 962-971. [CrossRef] [PubMed]

114. Kop, A.M.; Pabbruwe, M.B.; Keogh, C.; Swarts, E. Oxidation of Second Generation Sequentially Irradiated and Annealed Highly Cross-Linked X3 ${ }^{\mathrm{TM}}$ Polyethylene Tibial Bearings. J. Arthroplast. 2015, 30, 1842-1846. [CrossRef] [PubMed]

115. Bracco, P.; Oral, E. Vitamin E-stabilized UHMWPE for Total Joint Implants: A Review. Clin. Orthop. Relat. Res. 2011, 469, 2286-2293. [CrossRef] [PubMed]

116. Grassie, N.; Scott, G. Polymer Degradation and Stabilisation; Cambridge University Press: Cambridge, UK, 1985.

117. Berzen, J.; Luketic, D. Stabilised Polyethylene Moulding Materials, esp. for Implants-Containing Polyethylene with Molecular wt. 105-107, Antioxidant, and Tocopherol, esp. Alpha-Tocopherol or Vitamin E, as Stabiliser. Eur. Patent No. 613,923, 25 October 1994. 
118. Wolf, C.; Krivec, T.; Blassnig, J.; Lederer, K.; Schneider, W. Examination of the suitability of alpha-tocopherol as a stabilizer for ultra-high molecular weight polyethylene used for articulating surfaces in joint endoprostheses. J. Mater. Sci. Mater. Med. 2002, 13, 185-189. [CrossRef] [PubMed]

119. Tomita, N.; Kitakura, T.; Onmori, N.; Ikada, Y.; Aoyama, E. Prevention of fatigue cracks in ultrahigh molecular weight polyethylene joint components by the addition of vitamin E. J. Biomed. Mater. Res. 1999, 48, 474-478. [CrossRef]

120. Parth, M.; Aust, N.; Lederer, K. Studies on the effect of electron beam radiation on the molecular structure of ultra-high molecular weight polyethylene under the influence of $\alpha$-tocopherol with respect to its application in medical implants. J. Mater. Sci. Mater. Med. 2002, 13, 917-921. [CrossRef]

121. Kurtz, S.M.; Bracco, P.; Costa, L.; Oral, E.; Muratoglu, O.K. Vitamin E-Blended UHMWPE Biomaterials. In UHMWPE Biomaterials Handbook; Elsevier: Amsterdam, The Netherlands, 2016; pp. 293-306. [CrossRef]

122. Oral, E.; Muratoglu, O.K. Highly Cross-Linked UHMWPE Doped with Vitamin E. In UHMWPE Biomaterials Handbook; Elsevier: Amsterdam, The Netherlands, 2016; pp. 307-325. [CrossRef]

123. Oral, E.; Muratoglu, O.K. Vitamin E diffused, highly crosslinked UHMWPE: A review. Int. Orthop. 2011, 35, 215-223. [CrossRef] [PubMed]

124. Gijsman, P.; Smelt, H.J.; Schumann, D. Hindered amine light stabilizers: An alternative for radiation cross-linked UHMwPE implants. Biomaterials 2010, 31, 6685-6691. [CrossRef] [PubMed]

125. Fu, J.; Shen, J.; Gao, G.; Xu, Y.; Hou, R.; Cong, Y.; Cheng, Y. Natural polyphenol-stabilised highly crosslinked UHMWPE with high mechanical properties and low wear for joint implants. J. Mater. Chem. B 2013, 1, 4727. [CrossRef]

126. Narayan, V. Alternate Antioxidants for Orthopedic Devices. In UHMWPE Biomaterials Handbook; Elsevier: Amsterdam, The Netherlands, 2016; pp. 326-351. [CrossRef]

127. Shen, J.; Gao, G.; Liu, X.; Fu, J. Natural Polyphenols Enhance Stability of Crosslinked UHMWPE for Joint Implants. Clin. Orthop. Relat. Res. 2014, 473. [CrossRef] [PubMed]

128. Hope, N.; Bellare, A. A Comparison of the Efficacy of Various Antioxidants on the Oxidative Stability of Irradiated Polyethylene. Clin. Orthop. Relat. Res. 2015, 473, 936-941. [CrossRef] [PubMed]

129. Bracco, P.; Brunella, V.; Zanetti, M.; Luda, M.P.; Costa, L. Stabilisation of ultra-high molecular weight polyethylene with Vitamin E. Polym. Degrad. Stab. 2007, 92, 2155-2162. [CrossRef]

130. Costa, L.; Carpentieri, I.; Bracco, P. Post electron-beam irradiation oxidation of orthopaedic Ultra-High Molecular Weight Polyethylene (UHMWPE) stabilized with vitamin E. Polym. Degrad. Stab. 2009, 94, 1542-1547. [CrossRef]

131. Lerf, R.; Zurbrügg, D.; Delfosse, D. Use of vitamin E to protect cross-linked UHMWPE from oxidation. Biomaterials 2010, 31. [CrossRef] [PubMed]

132. Oral, E.; Greenbaum, E.S.; Malhi, A.S.; Harris, W.H.; Muratoglu, O.K. Characterization of irradiated blends of $\alpha$-tocopherol and UHMWPE. Biomaterials 2005, 26, 6657-6663. [CrossRef] [PubMed]

133. Kurtz, S.M.; Dumbleton, J.; Siskey, R.S.; Wang, A.; Manley, M. Trace concentrations of vitamin E protect radiation crosslinked UHMWPE from oxidative degradation. J. Biomed. Mater. Res. Part A 2009, 90, 549-563. [CrossRef] [PubMed]

134. Oral, E.; Wannomae, K.K.; Rowell, S.L.; Muratoglu, O.K. Diffusion of vitamin E in ultra-high molecular weight polyethylene. Biomaterials 2007, 28, 5225-5237. [CrossRef] [PubMed]

135. Kohm, A.; Furmanski, J.; Pruitt, L. Effect of alpha-tocopherol on UHMWPE fatigue resistance. In Transactions of the 52nd Orthopedic Research Society; Orthopaedic Research Society: Chicago, IL, USA, 2006; p. 662.

136. Oral, E.; Wannomae, K.K.; Hawkins, N.; Harris, W.H.; Muratoglu, O.K. $\alpha$-Tocopherol-doped irradiated UHMWPE for high fatigue resistance and low wear. Biomaterials 2004, 25, 5515-5522. [CrossRef] [PubMed]

137. Oral, E.; Christensen, S.D.; Malhi, A.S.; Wannomae, K.K.; Muratoglu, O.K. Wear Resistance and Mechanical Properties of Highly Cross-linked, Ultrahigh-Molecular Weight Polyethylene Doped With Vitamin E. J. Arthroplast. 2006, 21, 580-591. [CrossRef] [PubMed]

138. Bellare, A.; D'Angelo, F.; Ngo, H.D.; Thornhill, T.S. Oxidation resistance and abrasive wear resistance of vitamin E stabilized radiation crosslinked ultra-high molecular weight polyethylene. J. Appl. Polym. Sci. 2016, 133. [CrossRef]

139. Affatato, S.; Bracco, P.; Costa, L.; Villa, T.; Quaglini, V.; Toni, A. In vitro wear performance of standard, crosslinked, and vitamin-E-blended UHMWPE. J. Biomed. Mater. Res. Part A 2012, 100A. [CrossRef] [PubMed] 
140. Haider, H.; Weisenburger, J.N.; Kurtz, S.M.; Rimnac, C.M.; Freedman, J.; Schroeder, D.W.; Garvin, K.L. Does Vitamin E-Stabilized Ultrahigh-Molecular-Weight Polyethylene Address Concerns of Cross-Linked Polyethylene in Total Knee Arthroplasty? J. Arthroplast. 2012, 27, 461-469. [CrossRef] [PubMed]

141. Schwiesau, J.; Fritz, B.; Kutzner, I.; Bergmann, G.; Grupp, T.M. CR TKA UHMWPE Wear Tested after Artificial Aging of the Vitamin E Treated Gliding Component by Simulating Daily Patient Activities. BioMed Res. Int. 2014, 2014, 1-9. [CrossRef] [PubMed]

142. Vaidya, C.; Alvarez, E.; Vinciguerra, J.; Bruce, D.A.; DesJardins, J.D. Reduction of Total Knee Replacement Wear with Vitamin E Blended Highly Cross-Linked Ultra-High Molecular Weight Polyethylene. Proc. Inst. Mech. Eng. Part H J. Eng. Med. 2011, 225, 1-7. [CrossRef] [PubMed]

143. Teramura, S.; Sakoda, H.; Terao, T.; Fujiwara, K.; Kawai, K.; Tomita, N. Reduction of Wear Volume from Accelerated Aged UHMWPE Knee Components by the Addition of Vitamin E. J. Biomech. Sc. Eng. 2009, 4, 589-596. [CrossRef]

144. Bladen, C.L.; Teramura, S.; Russell, S.L.; Fujiwara, K.; Fisher, J.; Ingham, E.; Tomita, N.; Tipper, J.L. Analysis of wear, wear particles, and reduced inflammatory potential of vitamin $\mathrm{E}$ ultrahigh-molecular-weight polyethylene for use in total joint replacement. J. Biomed. Mater. Res. Part B Appl. Biomater. 2013, 101B, 458-466. [CrossRef] [PubMed]

145. Bichara, D.A.; Malchau, E.; Sillesen, N.H.; Cakmak, S.; Nielsen, G.P.; Muratoglu, O.K. Vitamin E-Diffused Highly Cross-Linked UHMWPE Particles Induce Less Osteolysis Compared to Highly Cross-Linked Virgin UHMWPE Particles In Vivo. J. Arthroplast. 2014, 29, 232-237. [CrossRef] [PubMed]

146. Banche, G.; Allizond, V.; Bracco, P.; Bistolfi, A.; Boffano, M.; Cimino, A.; Brach Del Prever, E.M.; Cuffini, A.M. Interplay between surface properties of standard, vitamin $\mathrm{E}$ blended and oxidised ultra high molecular weight polyethylene used in total joint replacement and adhesion of Staphylococcus aureus and Escherichia coli. Bone Jt. J. 2014, 96B. [CrossRef] [PubMed]

147. Banche, G.; Bracco, P.; Allizond, V.; Bistolfi, A.; Boffano, M.; Cimino, A.; Brach del Prever, E.M.; Cuffini, A.M. Do Crosslinking and Vitamin E Stabilization Influence Microbial Adhesions on UHMWPE-based Biomaterials? Clin. Orthop. Relat. Res. 2014, 473. [CrossRef] [PubMed]

148. Banche, G.; Bracco, P.; Bistolfi, A.; Allizond, V.; Boffano, M.; Costa, L.; Cimino, A.; Cuffini, A.M.; Brach del Prever, E.M. Vitamin e blended Uhmwpe may have the potential to reduce bacterial adhesive ability. J. Orthop. Res. 2011, 29. [CrossRef] [PubMed]

149. Scemama, C.; Anract, P.; Dumaine, V.; Babinet, A.; Courpied, J.P.; Hamadouche, M. Does vitamin E-blended polyethylene reduce wear in primary total hip arthroplasty: A blinded randomised clinical trial. Int. Orthop. 2017, 41, 1113-1118. [CrossRef] [PubMed]

150. Shareghi, B.; Johanson, P.-E.; Kärrholm, J. Femoral Head Penetration of Vitamin E-Infused Highly Cross-Linked Polyethylene Liners. J. Bone Jt. Surg.-Am. Vol. 2015, 97, 1366-1371. [CrossRef] [PubMed]

151. Salemyr, M.; Muren, O.; Ahl, T.; Bodén, H.; Chammout, G.; Stark, A.; Sköldenberg, O. Vitamin-E diffused highly cross-linked polyethylene liner compared to standard liners in total hip arthroplasty. A randomized, controlled trial. Int. Orthop. 2015, 39, 1499-1505. [CrossRef] [PubMed]

152. Sillesen, N.H.; Greene, M.E.; Nebergall, A.K.; Huddleston, J.I.; Emerson, R.; Gebuhr, P.; Troelsen, A.; Malchau, H. 3-year follow-up of a long-term registry-based multicentre study on vitamin E diffused polyethylene in total hip replacement. Hip Int. 2016, 26, 97-103. [CrossRef] [PubMed]

153. Nebergall, A.K.; Troelsen, A.; Rubash, H.E.; Malchau, H.; Rolfson, O.; Greene, M.E. Five-Year Experience of Vitamin E-Diffused Highly Cross-Linked Polyethylene Wear in Total Hip Arthroplasty Assessed by Radiostereometric Analysis. J. Arthroplast. 2016, 31, 1251-1255. [CrossRef] [PubMed]

154. Rowell, S.L.; Muratoglu, O.K. Investigation of surgically retrieved, vitamin E-stabilized, crosslinked UHMWPE implants after short-term in vivo service. J. Biomed. Mater. Res. Part B Appl. Biomater. 2016, 104, 1132-1140. [CrossRef] [PubMed]

155. Currier, B.H.; Currier, J.H.; Holdcroft, L.A.; van Citters, D.W. Effectiveness of anti-oxidant polyethylene: What early retrievals can tell us. J. Biomed. Mater. Res. Part B Appl. Biomater. 2017. [CrossRef] [PubMed]

(C) 2017 by the authors. Licensee MDPI, Basel, Switzerland. This article is an open access article distributed under the terms and conditions of the Creative Commons Attribution (CC BY) license (http:/ / creativecommons.org/licenses/by/4.0/). 